\title{
تطوير منهج الكيمياء بالمرحلة الثانوية في ضوء المفاهيم المستعرضة التضمنة في معايير الجيل القادم للعلوم
}

سمر شls d d d d d

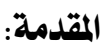

للتعامل بشكل إيجابي مع هذه الثورة المعرفية ، لذا شهدت الساحة التربوية سلسلة متتاليــة من بر امج ومشاريع إصلاح تعلـِيم العلــوم سواءً على المستوى العالمي أو على مستوى لرى المؤسسات و الهيئات المحلية المتخصــصة، وقد تتوَّعت وتعدَّدت بر امج التطوير بـشكل مطرّد خلال العقود الماضية وقادت الولايات المتحدة الأمريكية عملية إصلاح التعليم منذ أن أدركت ذلـــ National Research

.Council ,1996,100)

وقد قام المركز القومي للبحوث فــي

الو لايات المتحـــدة الامريكيــة ) National Research Council "(NRC من الهيئات و المؤسسات مثـــل: الأكاديميــة

"National Academy " الوطنية للعلوم of Science (NAS) National Science لمعلمــي العلـــوم (.NSTA) "Teachers Association " ومنظمة (Achieve) • بيناء معايير الجيـل القــادم للعـــوم The Next Generation) - "Science Standards) "NGSS National Research Council , ) $\cdot(2012,5$
لا شَكََّّ أنَّ العصر الحالي هو عَــر

التغير ات المتلاحقة ، و المعلومات المتز ايدة ، و التطور ات المعرفية التي تؤثر في أســاليب

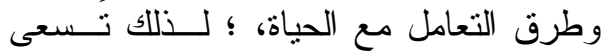

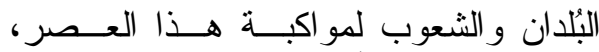

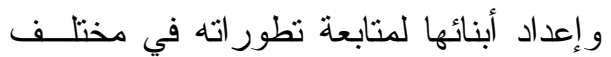

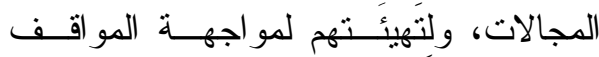
الحياتية المختلفة حيث يتميز العصر الحــالي بسرعة النمو المعرفي و التقني، الأمر الــذي يؤثز في حياة أفراد المجتمع؛ لذا فرض هذا الواقع على صانعي القــرار التربــــي فــي مختلف دول العالم مسئوليةً مو اكبة التطور ات و التغيير ات بإيجابية، و المساهمة فـــي إنتـــاج المعرفة و استخدامها في المجـــالات العلميــة المختلفة، من أجل تأهيل الأفــر اد ليكونـــوا قــادرين علــى المو اعمـــة بــين مهـــار اتهم ومتطلبـــات القــرن الحـــالي ، و وهــــا مــــا حدا بالتربويين إلى توجيه اهتمامــاتهم فــي مطلع القرن الو احد و العشرين إلــى ثرســيخ فكرة تطوير المناهج فـي ضـــوء المعـــيير العالمية .

فأصبح من الضروري على الفرد أن

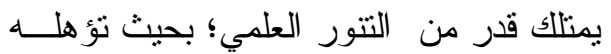


• التكامل التـامّ بــين الثــورة الرقميــة و العملية التعليمية .

• دمج الهندسة في تعليم العلوم عن طريق

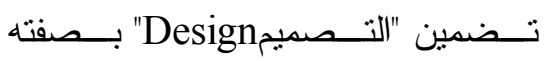
عنصر اً محورياً في تعليم العلوم •

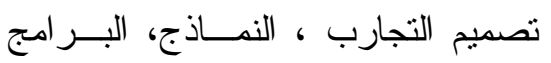

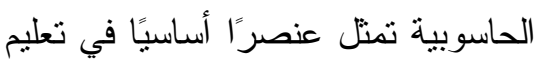
العلوم.

وأكدت العديد من الدر اســات علــى

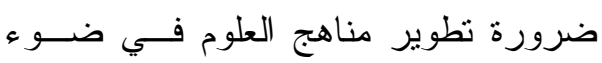
معايير الجيل القادم للعلوم ومنها : در اسة كل فل فيرج

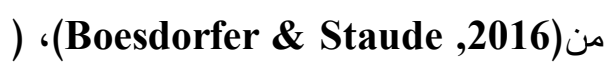

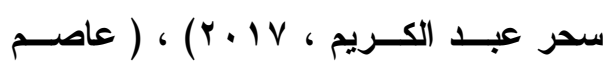

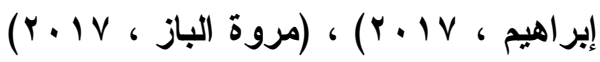

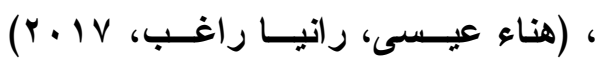

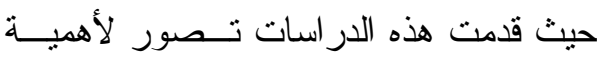
وكيفية نطوير مناهج العلوم في ضو ه معايير

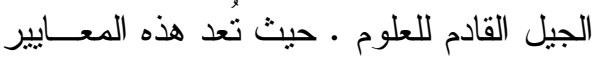

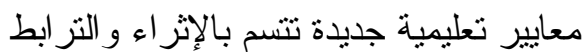
، شاملة لمختلف الموضـــوعات و المر احـل الدراسية، وتوفر لجميع الطــلاب مـستويً

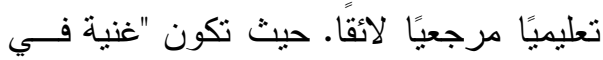
المحتوى و التطبيق، ومُرنبة بطريقة منسـقة لهنة عبر التخصصات و الصفوف الدر اسية مـن لطن أجل إمداد الطلاب بتعليم عـالي المـستوى للعلوم. وقد اشتركت بr و لاية فـي وضــع هذه المعايير • كما اثترك الجمهور أيضًا في
وفي عام 10 ب م م أصــدر المجلـس

الوطني للبحوث بأمريكا دليًا لكيفية تطبيــن و استخدام المعايير من أجل تحـسين تعلــيم

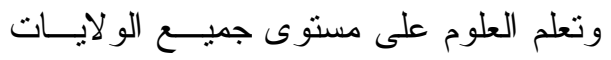

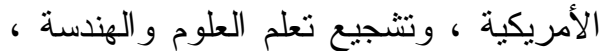
وجعل موضوعات العلوم و اقعًا حيًا يعيـشـه

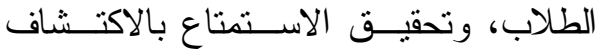

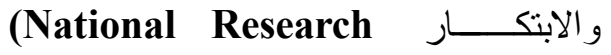
Council ,2015, 7) وكان الهذف الأسمى لوثيقة معسايير

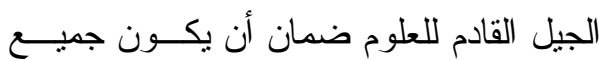

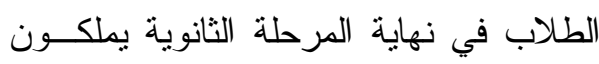

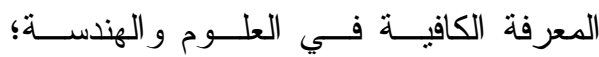
للمشاركة في مناقثنات عامة حول القـض ائايا المجتمعية ذات الصلة، كما يصبحون قادرين على مو اجهة المشكلات العلمية و التكنولوجية التي تو اجه حياتهم اليومية، ويــصبح لــديهم القدرة على الاستمرار في التعلم وطلب العلم

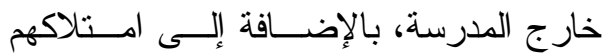

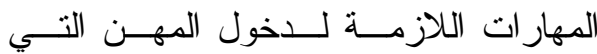
يختارونها، بما في ذللك وليس عـــى ســبيل الحصر ( وظائف في مجال العلوم و الهندســـة ولئة و التكنولوجيـا) ( NGSS Lead States, . (2013 a, 14 وتؤكد هذه المعايير على أهمية أربع ركائز

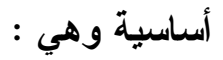
• الاتصال، و التعاون، و الإبداع، و التفكير - المنطقي 


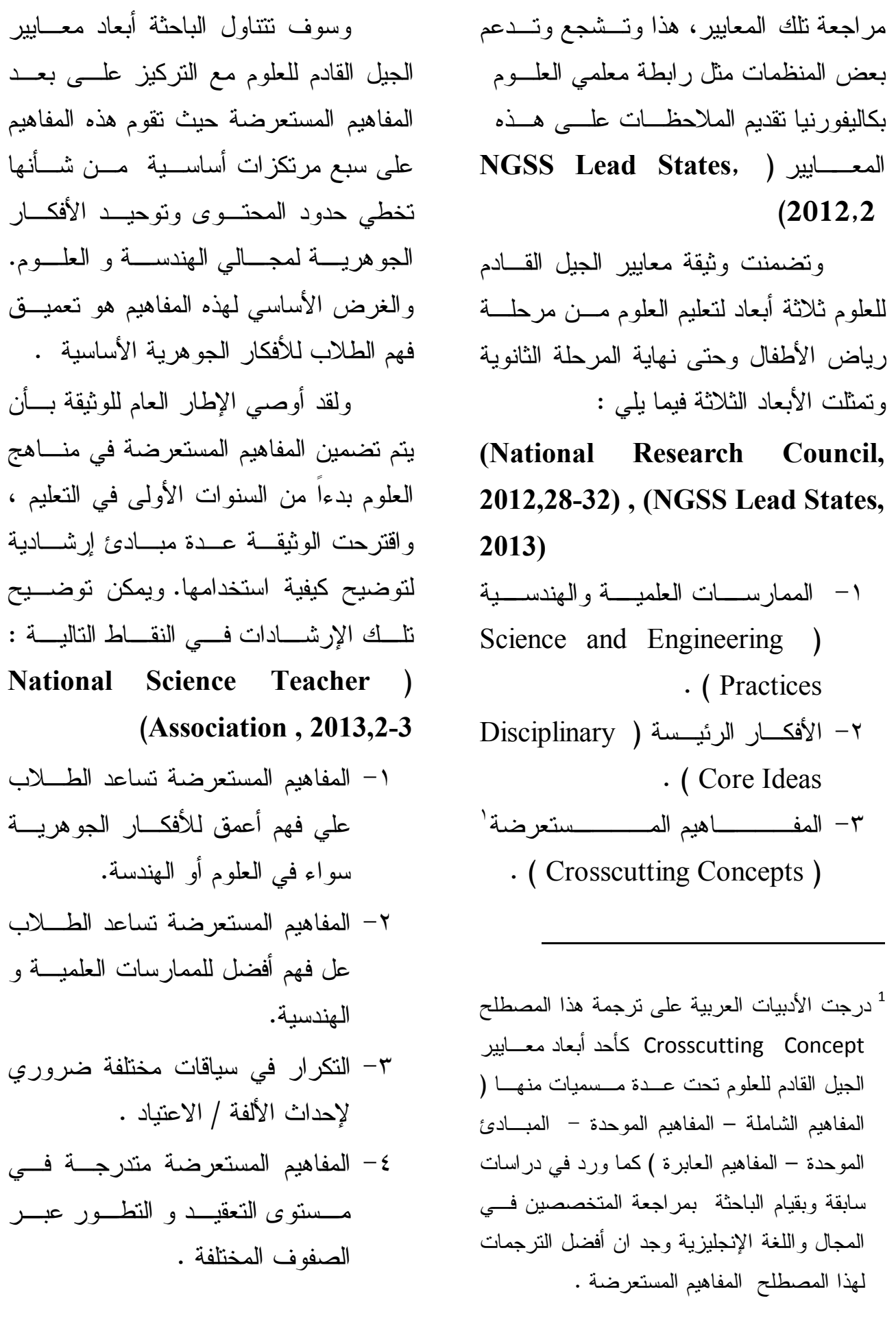


-و استشعرت الباحثة وجود مـشكلة مع يلى:

• باطلاع الباحثة على نتائج وتوصـيات

العديد من الدر اسات و البحوث الــسابقة

في مجال تطوير مناهج العلوم في ضوء

المعايير بشكل عام وفي ضوء معسايير

الجيل القادم للعلوم بشكل خاص ومنهـــا

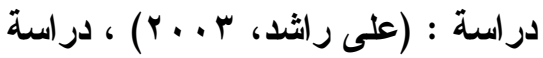

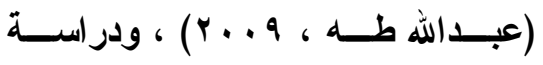

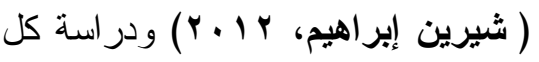

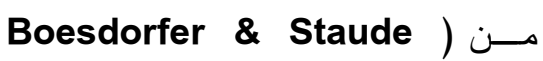

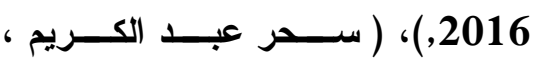

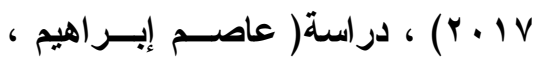

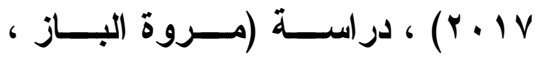

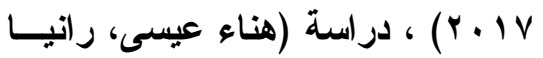

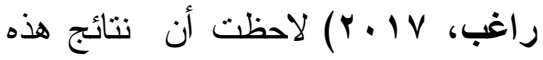

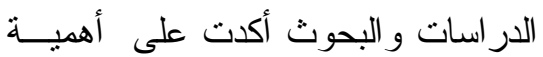

تطوير مناهج العلوم في ضوء المعايير

بالإضافة إلى ضعف تتاول منهج كيمياء

المرحلة الثانوية للمفاهيم المستسعرضة

التي نادت بها معــايير الجيــل القـــادم

للعلوم.

• نتائج الاراسة الاستطلاعية التي قامت

$$
\text { بها الباحثة : بانج }
$$

اســتهذفت الدر اســــة الاســـطلاعية

التعرف على مدى تلبية كتب الكيمياء الحالية

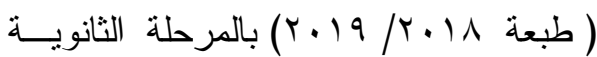

0- المفاهيم المستعرضة مـن شـأنها أن

تقدم مفاهيم عامة في مجالي العلوم و

الهندسة.

צ- المفاهيم المستعرضة لا يجب تقييمهـــا

منفصلة عن الممارســات و الأفكـار

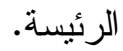

V- عند استخدام المفاهيم المستعرضة فإن

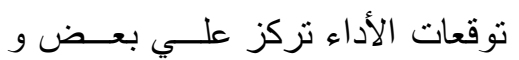

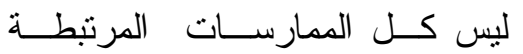

بالمفاهيم المستعرضة.

^- المفاهيم المستعرضة مناسبه لجميـع

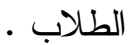

9- تضمين المفــاهيم الخاصـــة بطبيعــة

العلوم و الهندسة .

\section{الإحساس بالشكلة}

جاء الإحساس بالمشكلة مـن خــلال

الخبرة العملية لدى الباحثة في مجال تدريس

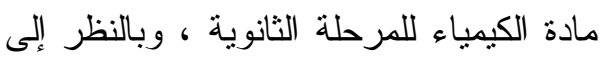
و اقع منهج كيمياء المرحلة الثانويــة تظهـر أهمية عملية تطوير المنهج بصورة مستمرة

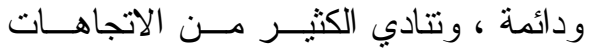
و المشروعات العالمية و العربية بأهمية تطبيق الانيق ودانيق

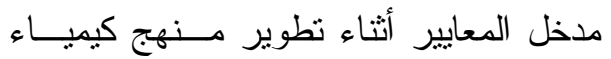
المرحلة الثانوية حيث يدور الهيكل الرئيسي

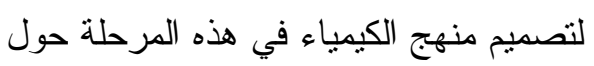

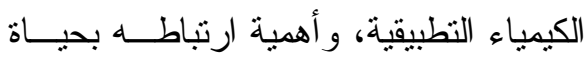

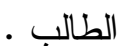


الاستبيان و الاختبار ات ، اتضح أهمية تطوير

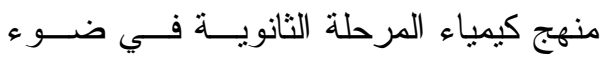
المفاهيم المستعرضة المتضمنة في معسايير الجيل القادم للعلوم (NGSS ) كبعـــ مسن فئن أبعاد التطوير حيث أعادت الباحثة صــياغة

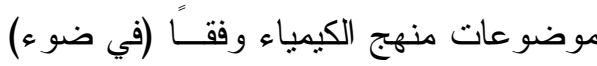
للمفاهيم المستعرضة كاتجاه جديد لتطـــــير

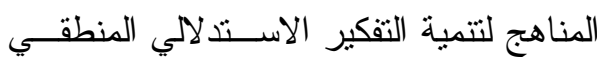
ومهار ات الاستقصاء العلمي ، ومن ثم أمكن تحديد مشكلة الدر اسة . ت الاسناء تخديد مشكلة البحث من خلال العرض السابق للأدبيــات و الدراسات السابقة ، اتضح أن هناك مشكلة

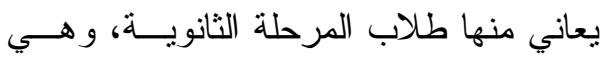

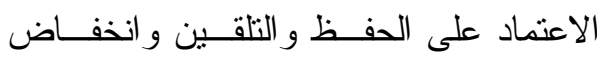
دافعيتهم نحو ممارســـة الأنــشطة العلميــة

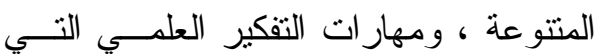
تساعدهم في مو اجهــة بعـض المـشكلات

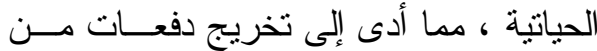
الطلاب لا يمكنهم التفكير في وقائع الحقــائق المتجددة و المشكلات التي قد يو اجهونها فــي

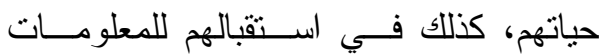
وفثلهم في ربطها بالخبرات السابقة لــديهم بشكل صحيح. فهم يتعلمون بطرق تقليدية لا

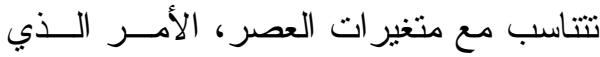
أدى إلى إهدار طاقات أجيال بــدون إفــادة حقيقية ، الأمر الذي يدعونا إلى النظر إلـى إلى الـى

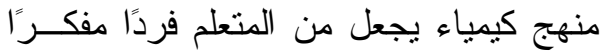

للمفاهيم المستعرضة من وجهة نظر معلمي الكيمياء، حيث تم تطبيق استبيان علي (· (r) عشرين من معلمي وموجهي مادة الكيميــاء

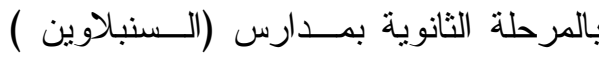

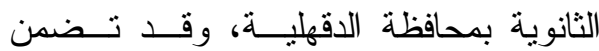
الاستبيان قائمة بالمؤشرات الخاصة بالمفاهيم

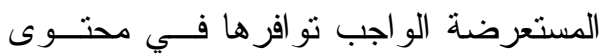
منهج كيمياء المرحلة الثانوية في ضو اءو وثئية

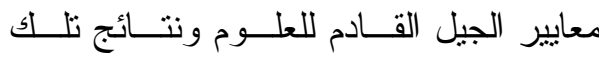
الاستبيان ؛ للتعرف على مدى تضمين منهج

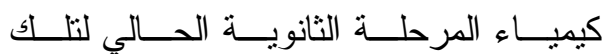
المؤشر ات ، وقد أوضحت نتائج الاســنتيان

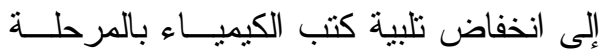

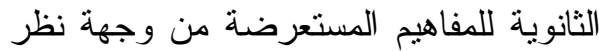
المعلمين : • اختبار مبائي: لكـلـ مــن ( المفــاهيم

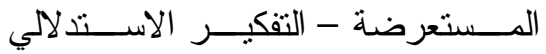
المنطقي - الاستقصاء العلهـي) على العى مجموعة استطلاعية من طلاب مدرسة

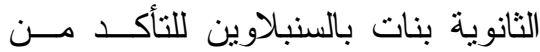
صحة اختبار المتغيرات تابعة.

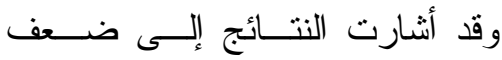
مستوى الطلاب في الثلاث اختبار ات حيــث تز اوحت درجاتهم من( · - ع) فـي حسين كانت الدرجة الكلية من · ا درجات . وبناءً على خبرة الباحثة في الميــدان

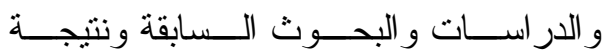


؟ - ما فاعلية تدريس وحدني ( الكيميــاء

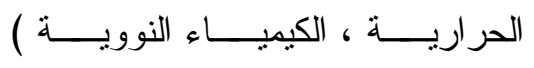

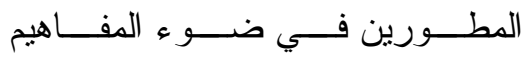

المستعرضة المتـــنة فــي معـايير

الجيل القادم للعلوم (NGSS) في تتمية

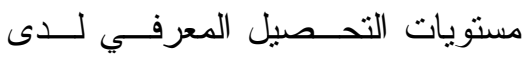

طلاب الصف الأول الثانوي ؟ ملتيات

0- ما فاعلية تدريس وحدتي ( الكيميــاء

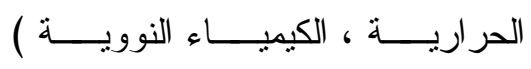

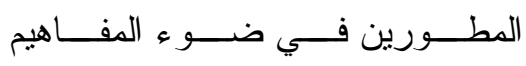

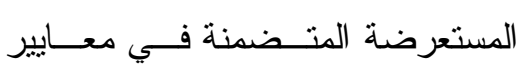

الجيل القادم للعلوم (NGSS) في تتمية

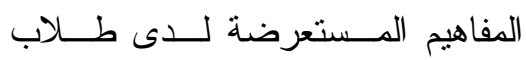

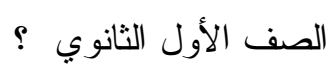

7- ما فاعلية تدريس وحدتي ( الكيميــاء

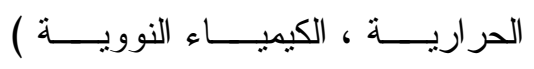

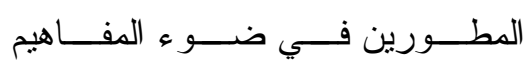

المستعرضة المت ضمنة فــي معسايير

الجيل القادم للعلوم (NGSS) في تتمية

التفكير الاستدلالي المنطقي لدى طلاب

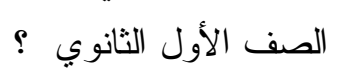

- V ما فاعلية تدريس وحدتي ( الكيميــاء

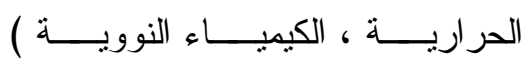

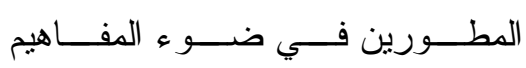

المستعرضة المت ضمنة فــي معسايير

الجيل القادم للعلوم (NGSS) في تتمية

الاستقصاء العلمي لدى طلاب الــصف

الأول الثانوي ؟ الأوباء
بنفسه، لا يقف عند حدود المعلومسـة التـي

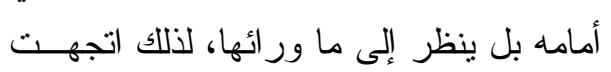

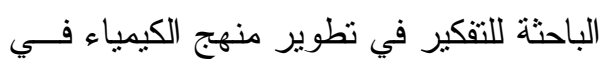

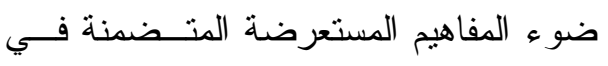
معايير الجيل القادم اللعلوم ولذلك تم صياغة مشكلة البحث الحالي فــي التساؤل الرئيس التالي:

كيف يمكن تطــوير مــنهج كيميـاء

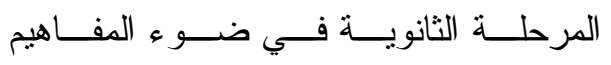

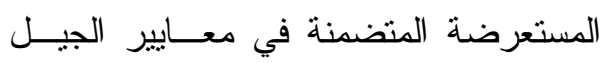

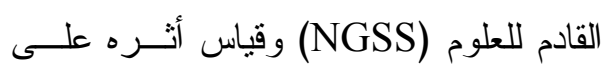

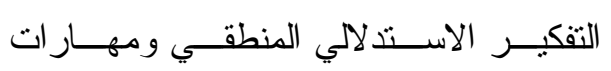

الاستقصاء العلمي ؟

ويتفرع من هذا السؤال الأســـئة الفرعيــة

\section{التالية : ونئزع}

1- ما هي المفاهيم المستعرضة المتضمنة

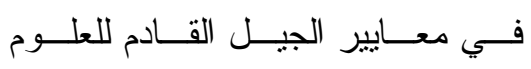

التي يجب تو افرها في منهج (NGSS)

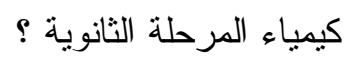

r- ما مدى مر اعاة محتوى منهج كيمياء

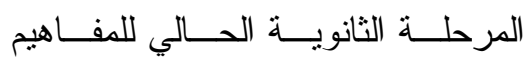

المستعرضة المت ضمنة فـي معسايير

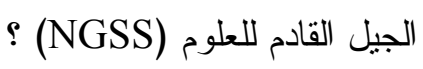

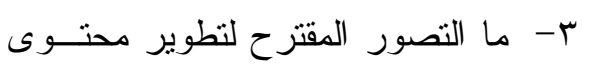

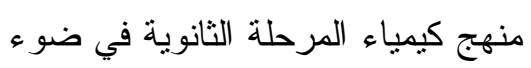

المفاهيم المستعرضة المت ضمنة فئسي

معايير الجيل القادم للعلوم (NGSS) ؟ 
المجمو عتنين الضابطة و التجريبية فــي

التطبيق البعدي للاختبــار التحـــيلي ولئي لصالح المجمو عة التجريبية.

r-يوجد فرق دال إحصائيًا عند مـستوى

(0. . •) بين منتوسطي درجات طـــلاب

المجموعة التجريبية في التطبيق القبلي

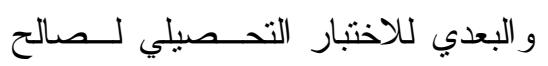

التطبيق البعدي.

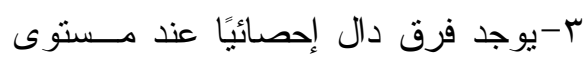

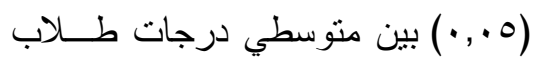

المجموعة التجريبية، وطلاب المجموعة لهن

الضابطة في النطبيق البعدي لاختبــار

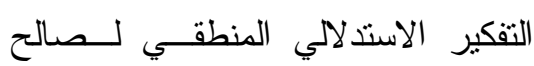

طلاب المجموعة التجريبية.

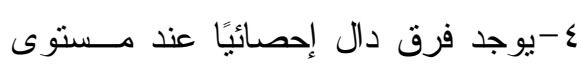

(0., •) بين متوسطي درجات طـــلاب

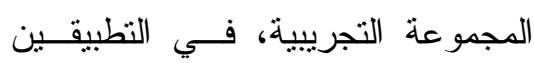

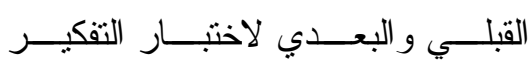

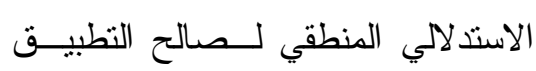

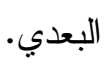

ه-يوجد فرق دال إحصائًا عند مسستوى

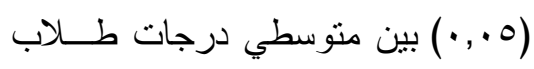

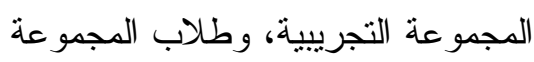

الضابطة في النطبيق البعدي لاختبــار

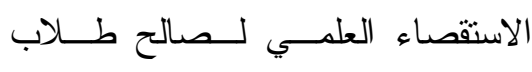

المجمو عة التجريبية.

7-يوجد فرق دال إحصائيًا عند مسستوى

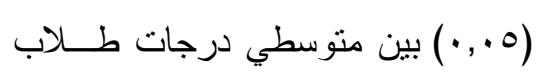

\section{استهرف البحث الحالي ما يلي :}

1- تحديد المفاهيم المستعرضة المتضمنة

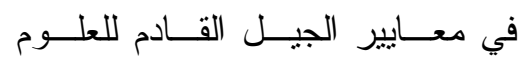

(NGSS)

منهج كيمباء المرحلة الثنانوية .

r- التعرف على مــدى مر اعـاة مـــــهج

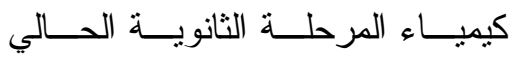

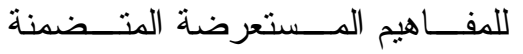

في معـايير الجيــل القــادم للعلـــوم

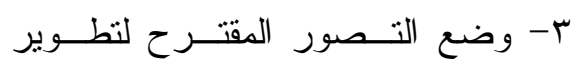

محتوى منهج كيمياء المرحلة الثانوية

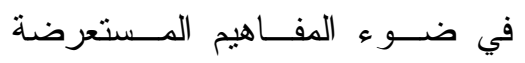

المتضمنة في معايير الجيـلـل القــادم

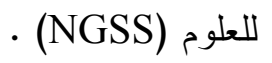

ع - قياس فاعلية تدريس وحدتي ( الكيمياء

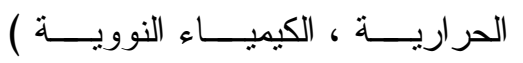

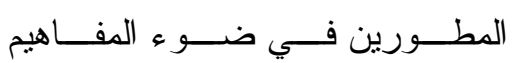

المستعرضة المتضمنة فـي معسايير

الجيـــل القـــادم للعلــــوم (NGSS)

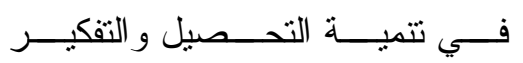

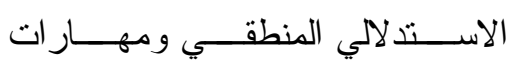

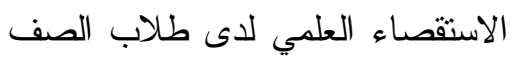
• الأول الثانوي

\section{فروض الدراسة}

1-يوجد فرق دال إحصائيًا عند مسستوى

(0. . • ) بين منوسطي درجات طـــلاب 
ع - كتـــاب الطالــــب وكر اســــة نــشـاط

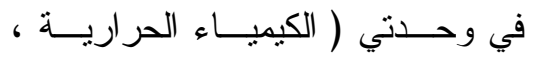

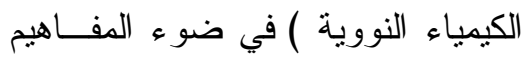

المستعرضة المت ضمنة فـي معسايير

الجيل القادم للعلوم (NGSS)

0- دليل المعلم فـي وحــني (الكيميــاء

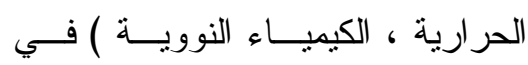

ضوء المفاهيم المستعرضة المتـضمنة

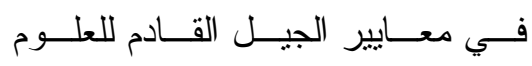

. (NGSS)

צ- اختبار تحصيلي في وحدتي ( الكيمياء

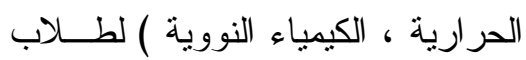

الصف الأول الثانوي التاءياء

V - اختبار التفكير الاستدلالي المنطقي في

مناهج العلوم لطــلاب الــــف الأول

$$
\text { الثانوي - النان }
$$

1- اختبار مهارات الاستقصاء العلمي في

مناهج العلوم لطــلاب الــــف الأول

$$
\text { • الثانوي - (الثان }
$$

9- اختبــار المفــاهيم المـستعرضة فـي

مناهج العلوم لطــلاب الــصف الأول

• الثانوي

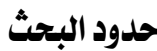

1- مجموعة من طلاب المرحلة الثانويــة

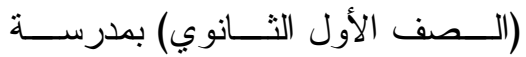

"العنانية الثانويــة ببر ههتــــ" إدارة

السنبلاوين التعليمية- محافظة الدقهلية
المجموعة التجريبية، فــي التطبية

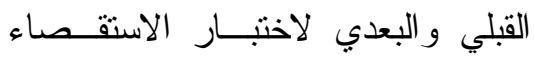
العلمي لصالح النطبيق البعدي.

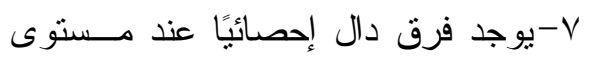

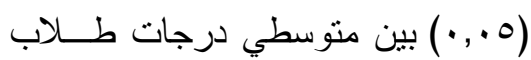

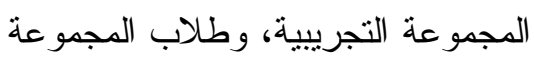

الضابطة في النطبيق البعدي لاختبـــار

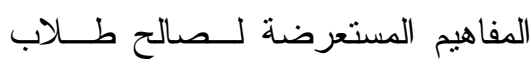

المجمو عة التجريبية.

^- يوجد فرق دال إحصائيًا عند مستوى

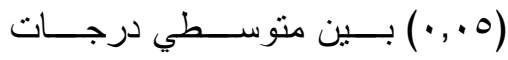

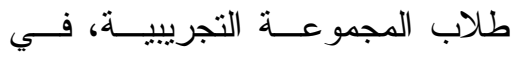

النطبيقين القبلي و البعــدي لاختبــار

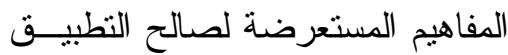

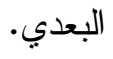

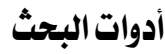

1- قائمة بالمفاهيم المستعرضة المت ضمنة

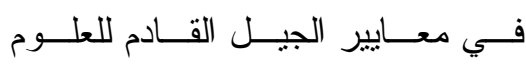

اللازم تو افرها في مــنهج (NGSS)

كيمياء المرحلة الثانوية .

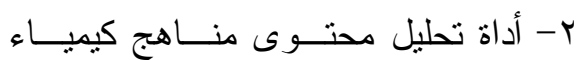

المرحلة الثانوية في ضـــوء المفـــاهيم

$$
\text { المستعرضة . }
$$

r- تصور مقترح لنطوير مــنهج كيميــاء

المرحلة الثانوية في ضــــوء المفــاهيم

المستعرضة المت ضمنة فـي معسايير

الجيل القادم للعلوم (NGSS). 


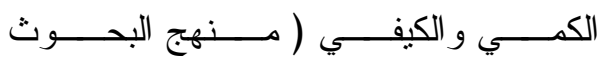

( Mixed Methods Research المختلطة الذي عرفه (Creswell , 2014, 43) بأنه طريقة لجمع وتحليل ومزج البيانات الكيفيــة

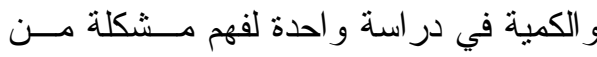
مشكلات البحث؛ وذلك في جو انبه:

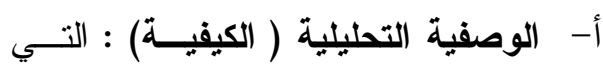
تتمثل في استقر اء البحوث و الدراســات التهات

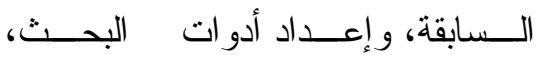

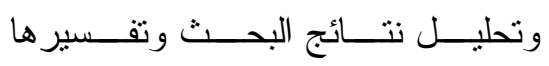
ومناقشتنها.

ب- الشبه تجريبية ( الكمية) : التي تمثنـل

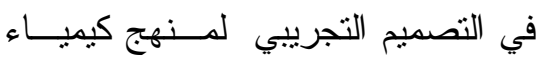

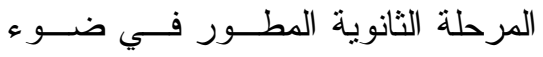

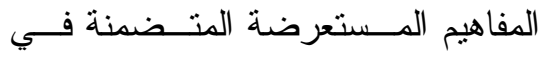
، معايير الجيل القادم للعلوم (NGSS) وذلك عن طريق تقسيم مجموعة البحث إلى مجمو عتين:

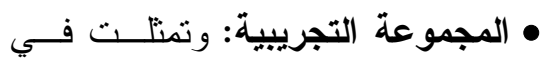

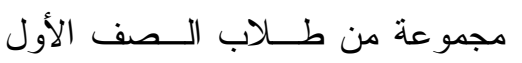
الثانوي تم تدريس المنهج المطور لها

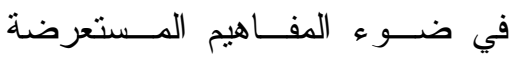
المتضمنة في معايير الجيـلـل القـادم

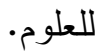

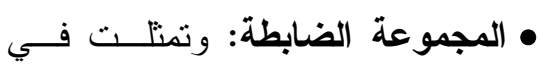
مجموعة من طــلاب الــصف الأول

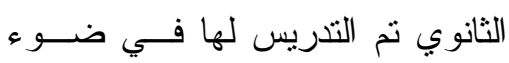
· المنهج الحالي
كمجموعــة تجريبيــة وعــددها (Y) طالبة ، ومدرسة" السنبلاوين الثانويـــة وعنة

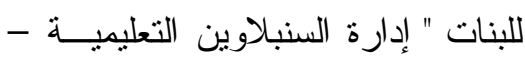
محافظة الدقهلية كمجموعــة ضــابطة

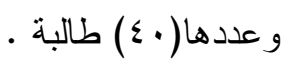
r- طبق البحث في الفصل الدراسي الثاني

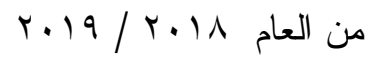
r- وحدتا ( الكيمياء الحرارية ، الكيميــاء

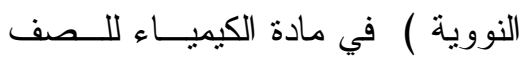
الأول الثانوي (الفصل الدراسي الثاني

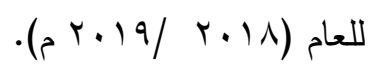

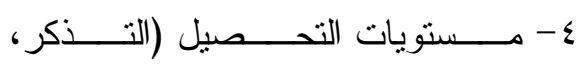
الفهم، التطبيق ، المستويات العليا فـي الـي (التفكير) ه- التقكير الاستدلالي المنطقي : ويتضمن

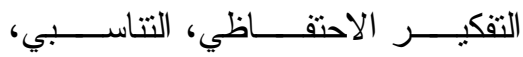
الاحتمـــالي، الارتبـــاطي، التــــو افقي،

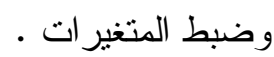

צ- مهارات الاستقصاء العلمي : وتتضمن

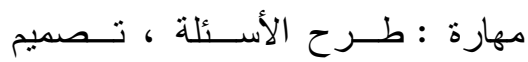

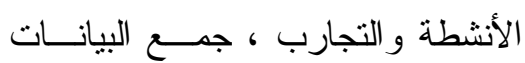

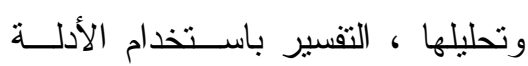

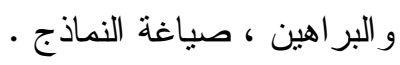

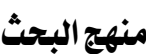
استخدم فـي هــذا البحــث المــنهج

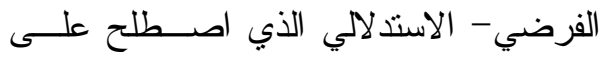
تسميته المنهج العلمي في البحث أو المــدخل 
المستعرضة المت ضمنة فــي معسايير

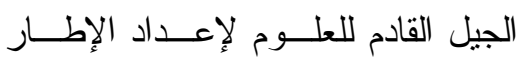
النظري و أدو ات البحث.

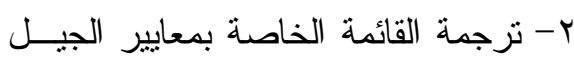
القادم للعلوم مــن الوثيقـــة الأساســـية للمعايير مع التزكيز علي بعد المفاهيم المستعرضة .

r- عمل استبيان لمعلمي وموجهي مسادة

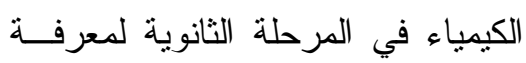
مدى تو افر المعايير في المنهج • عاءئ

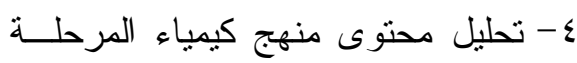
الثانوية في ضوء المفاهيم المستعرضة المتضمنة في معسايير الجيـلـ القـــادم

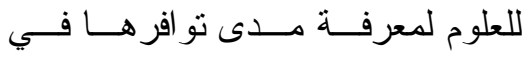
المنهج. 0- اختيار المحتــوى العلمـي المناســب و الملائم لتوقيت نطبيق المنهج المطور

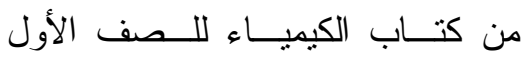
الثانوي/ الفصل الدراسي الثاني .

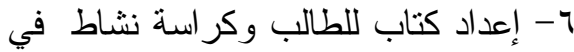
وحدتي (الكيمياء الحرارية ، الكيميــاء

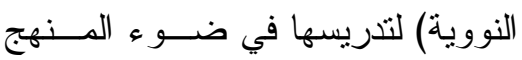

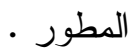
- V

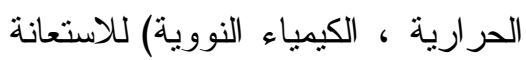

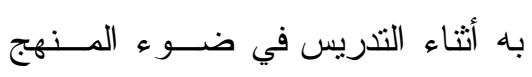

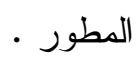

\section{التصميم التجرييي للبحث}

اعتمد البحث الحالي على المنهج شبه

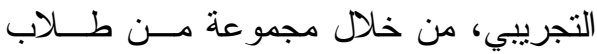
الصف الأول الثانوي مقسمة على مجمو عنين

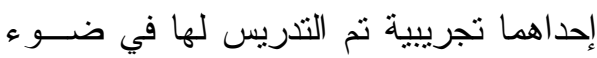

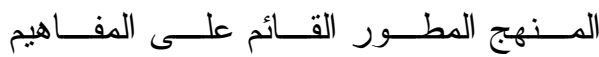

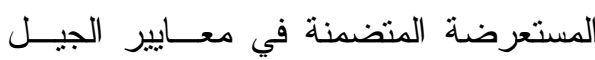

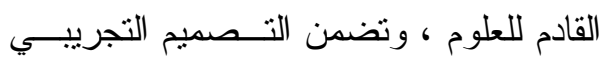
لهذا البحث على المتغير ات التالية:

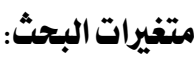
• المتغير المستقل: ويتمنل في: تطوير منهج كيمياء المرحلة الثانوية فـي في في ضو ء المفاهيم المستعرضة المتضمنة في معايير الجيل القادم للعلوم (NGSS) . • المتغير ات التابعة: وتتمنل في: أ- تحصيل المعلومات المرتبطة بوحسـني ولهي (الكيمياء الحر ارية ، الكيمياء النووية). ج- ب- التفكير الاستدلالي المنطقي . إجرايات البحث

تــــم اتبـــاع الإجـــــاعات التاليـــة للإجابـــة

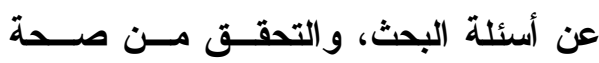
فروضه : - من أولأ : مرحلة الدراسة الكيفية :

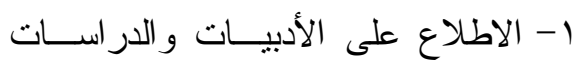
السابقة المتعلقة بتطوير منهج كيميـاء الاديـاء

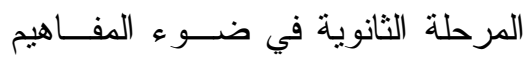




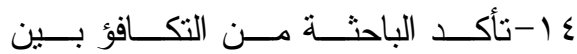

$$
\text { الأدمو عتين الضنابطة و التجريبية فـي }
$$

ثانيًا : مرحلة الدراسة الكمية :

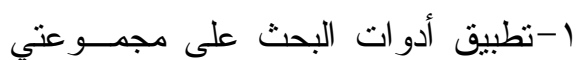

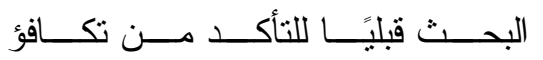

المجمو عتين.

ب-تدريس وحدتي ( الكيمباء الحراريـــة ،

الكيمياء النووية ) للمجموعة التجريبية

في ضوء المنهج المطور، وللمجموعة الضنابطة المنهج المعتاد.

r- تطبيق أدوات البحث بعديًا على طلاب المجمو عتين التجريبية و الضابطة. ع - تحليل النتــائج وتقــسير ها باســتخدام المعالجة الإحصائية للبيانات بالأســاليب

$$
\text { الإحصائية المناسبة. }
$$

0-تقديم التوصيات و البحوث المقترحة في ضوء ما أسفر عنه البحث الحالي مــن نتائج.

\section{مصطلحات البجث}

يتضمن البحث الحالي المصطلحات التالية:

- Standers معاييز الجيل القادم للعلوم

: Next Generation Science

عُرفت بأنها : مجموعة من توقعات

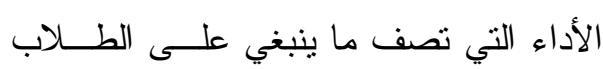
معرفته وما ينبغي القيام به وهـي معــيير

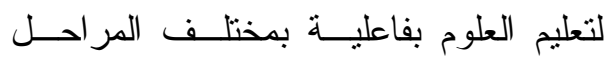

^- عرض أدوات البحث الـسابقة علـىى السادة المحكمين. 9- إعداد أدو ات البحث و المتمثلة في:

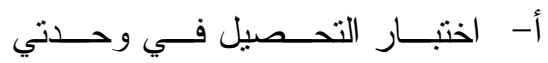

(الكيميــــاء الحر اريــــة ، الكيميـــــاء

النووية).

ب- اختبار المفاهيم المـستعرضة فــي

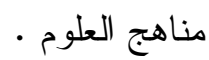

ج- اختبار التفكير الاستدلالي المنطقـي في مناهج العلوم ·

د - اختبار مهار ات الاستقصـاء العلمــي في مناهج العلوم ·

• 1-عرض أدوات البحث على مجموعـــة من السادة المحكمين؛ لتحديــــ مـــى ملاعمتها ومناسبتها لقياس ما وضعت من أجله.

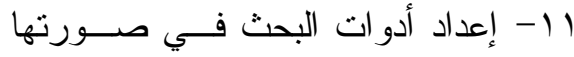
النهائية. rا - التأكد من صــدق وثبـــات الأدوات بتطبيقها على مجموعـة اســتطلاعية لتأكد من صدق وثبات الأدو ات . سا -اختيار مجموعة البحــث الأساســية و التي تمنتلت فــي طــلاب الــصف

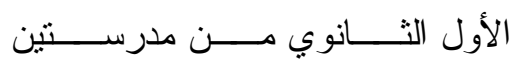

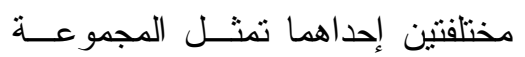

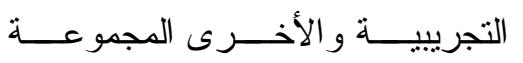
الضـابطة. 
المختلفة والتي تربط المجالات الأربعة للعلوم ببعضها البعض ( علــوم الحيــاة و العلـــوم

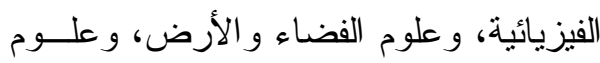

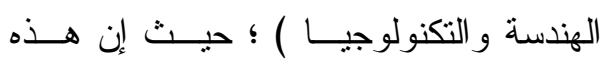

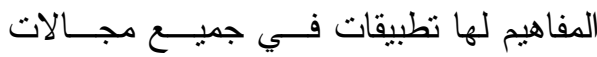

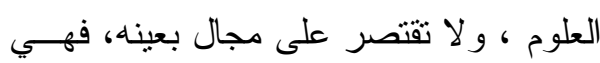

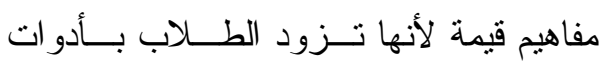

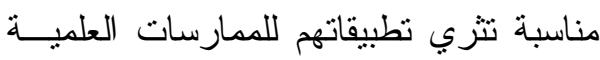
و الهندسية وفهمه للأفكار الرئيسة المحورية. National Science Teacher ) .(Association , 2013,1

rogical التفكير الاستدلالي المنطقي :Reasoning Thinking

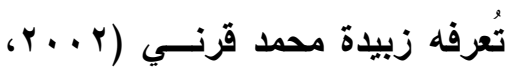

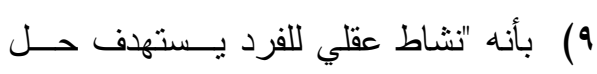
مشكلة ما أو اتخاذ قرار، وهو عملية تتضمن الوصول إلى نتيجة من مقــدمات معلومـــة،

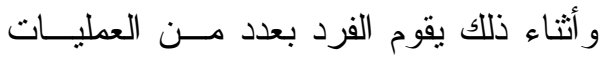
العقلية، وله أنماط مختلفة هـــي الاســتـلال النـسبي - ضــبط المتغيــر ات الاســـــلال الاحتمالي - الاستخلال الارنباطي - ثبــات

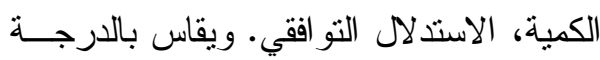

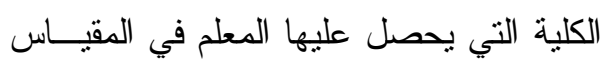
المعد لهذا الهذف .

وتعرفه الباحثة إجرائيًا أنـــه القــدرة

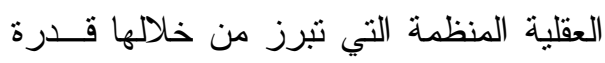

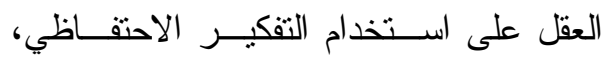

التعليمية من مرحلة رياض الأطفال وحتـى

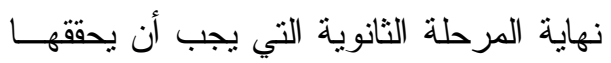

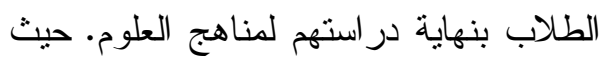
تعد هذه المعايير بمثابة محكات لجودة الأداء

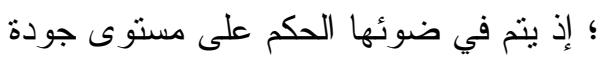
محتوى مناهج العلوم ، وتتضمن نثلاثة أبعاد

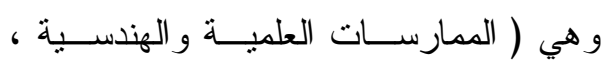

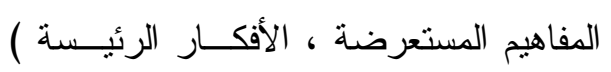
(NGSS Lead States, 2012,1) وعرفتها الباحثة إجرائيًا : بأنهــا

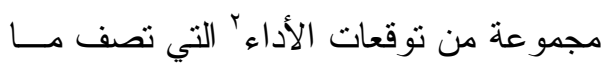

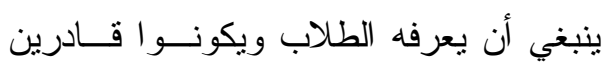
على القيام به بنهاية در استهم لمنهج كيميــاء

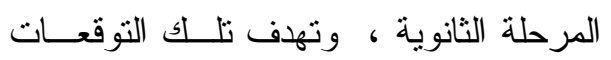

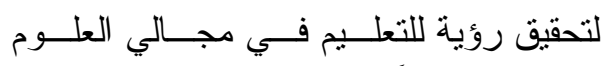

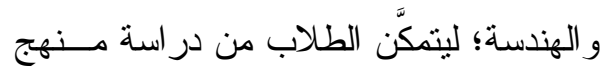

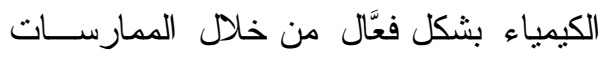

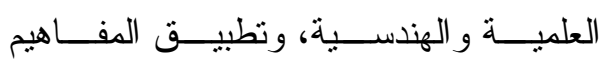

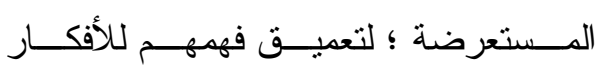

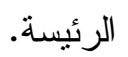

rosscutting المفاهيم المستعرضة

\section{: Concepts}

المفاهيم المستعرضة هي تلك المفاهيم

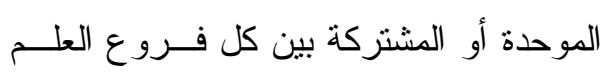

2 المقصود بتوقعات الأداء : ما ينبغي أن يكون الطلاب قادرون على معرفته و القيام بهد في نهاية الطادية

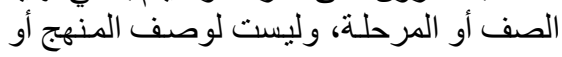

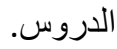


ما هي المفاهيم المستعرضة المتضمنة فــي معايير الجيل القادم للعلوم (NGSS) التــي

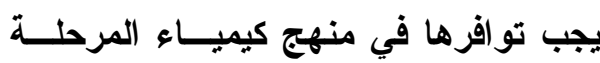

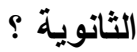

وتمت الإجابــة عـن هــذا الـسؤال

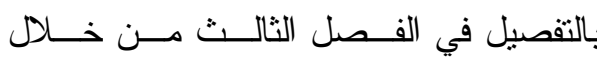
الإجر اءات التي نم اتباعها لبناء و إعداد قائمة

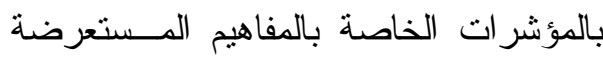

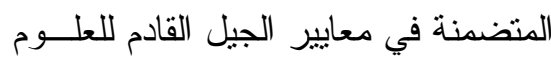
(NGSS)

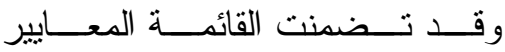
و المؤشر ات الو اجب نو افرها فــي محتــــى

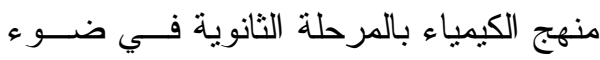
المفاهيم المستعرضة المتضمنة في معسايير

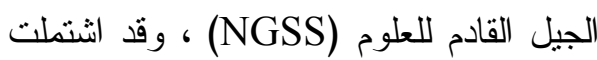
على ما يلي : .

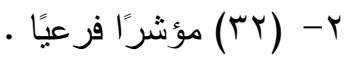

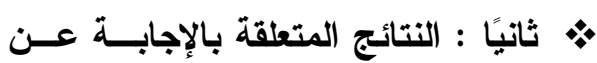
السؤال الثاني ، مناقشتها وتفسيرها : نص السؤال الثاني من أسئلة الدراســـة فئسة على : ما مدى مر اعاة محتــوى مــنهج كيميــاء

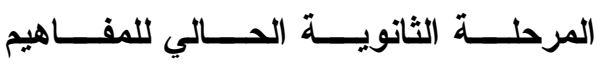

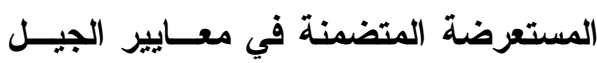
القادم للعلوم (NGSS) ( ل)
التناسبي، الاحتمالي، الارتباطي، التـــوافقي،

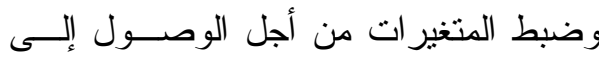

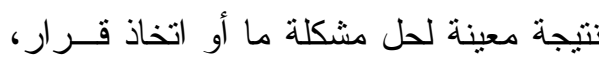
وهو عملية تتضمن الوصول إلى نتيجة مسن مقدمات معلومة.

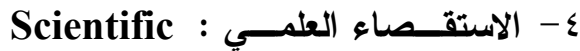

\section{Inquiry}

ويعرّف المجلس القــومي للبحــوث (1996, 214) NRC مجموعة من العمليات المتر ابطة التي يطرح فيها العلماء والطلاب أسئلتهم حـــول العــالم الطبيعي ويحققون في الظواهر المحيطة بهم،

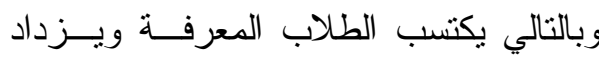

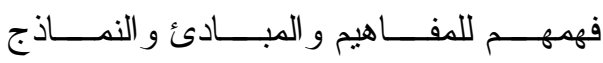

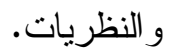

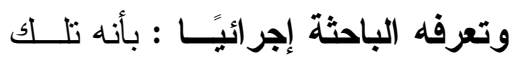

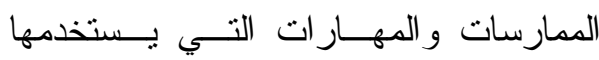

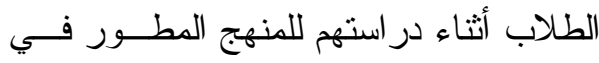

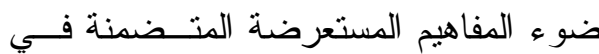
معايير الجيل القادم للعلوم في منهج الكيمياء من خلال البحث و التقصي عن طريق طرح

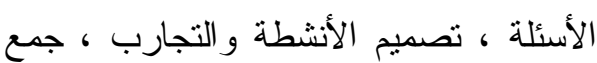

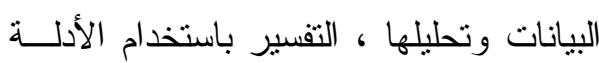
و البر اهين ، صياغة النماذج • نتائج البحث - مناقشتها وتفسيرها

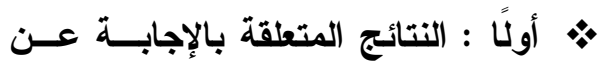

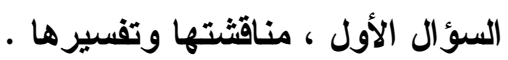
نص السؤال الأول من أسئلة الدر اسة على : 
r- نتائج الفحص الخاصة بالصف الثالــث

ولإجابة على هذا السؤ ال نم تحويــل

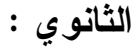

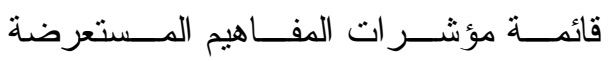

إجمالي اهتمام محتوى منهج كيميــاء

المتضمنة في معايير الجيل القادم للعلوم إلى مونى

الصف الثالث الثانوي الحــالي فــي ضـــوء لهاء

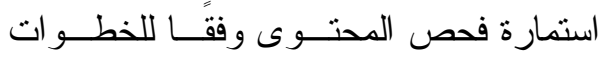

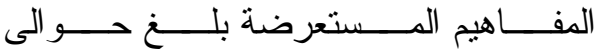

الإجر ائية الموضحة بالتقصيل فـــي الخطــــوة

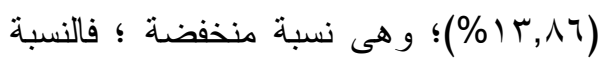

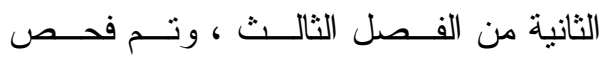

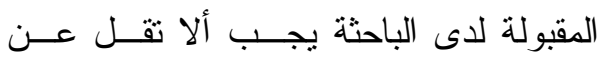

محتوى كتب الكيمياء و التي يدرسها الطلاب

في الصفوف الأول و الثاني و الثالث الثانوي ؛ لأن

في ضوء ما سبق يمكن استخلاص ما يلي :

وذللك للتعرف على مدى نو افر تلاك المفــاهيم خ ضعف درجة تتــاول محتــوى مسـنهج

فيها :وكثفت عملية الفحص على النتــائج

كيمياء الصفوف الثثلاثة الأولى بالمرحلة

التالية :

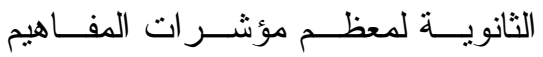

المستعرضة المنضمنة في معايير الجيل

القادم للعلوم بنسب منخفضة .

ه ضرورة تضمين محتوى منهج الكيمياء

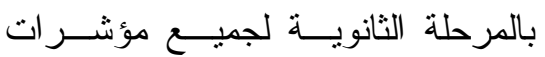

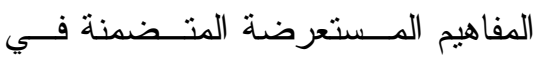

معايير الجيل القادم للعلوم ؛ وذلك بشكل

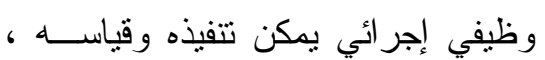

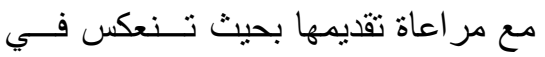

خبرات تعليمية مرتبطة بتعلم الطــلاب

ل للمحتوى - ل

ثالثًا : النتائج المتعلقة بالإجابـة عــن

السؤال الثالث ، مناقشتها وتفسيرها :

نص السؤ ال الثالث من أسئلة الدراسة على :

1- نتائج الفحص الخاصة بالـــف الأول

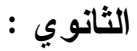

إجمالي اهتمام محتوى منهج كيميــاء

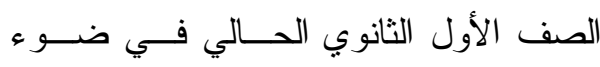

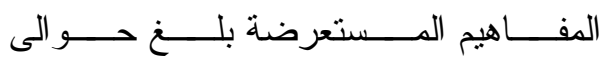

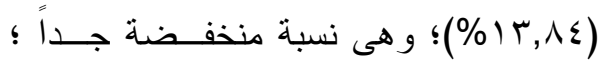

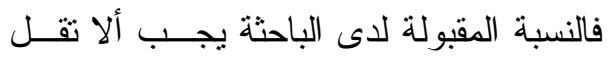

$$
\text { عن ( ) . (\%) }
$$

ץ - نتائج الفحص الخاصة بان بالصف الثـاني الثانوي :

إجمالي اهتمام محتوى منهج كيميــاء

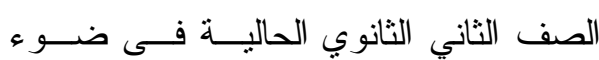

المفاهيم المستعرضة بلغ حوالى (r؟ع,\%)؛

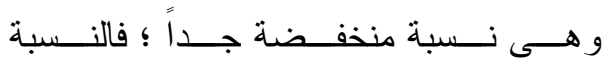

المقبولة لدى الباحثة يجــب ألا نقــل عــن

. $(\% \circ \cdot)$ 


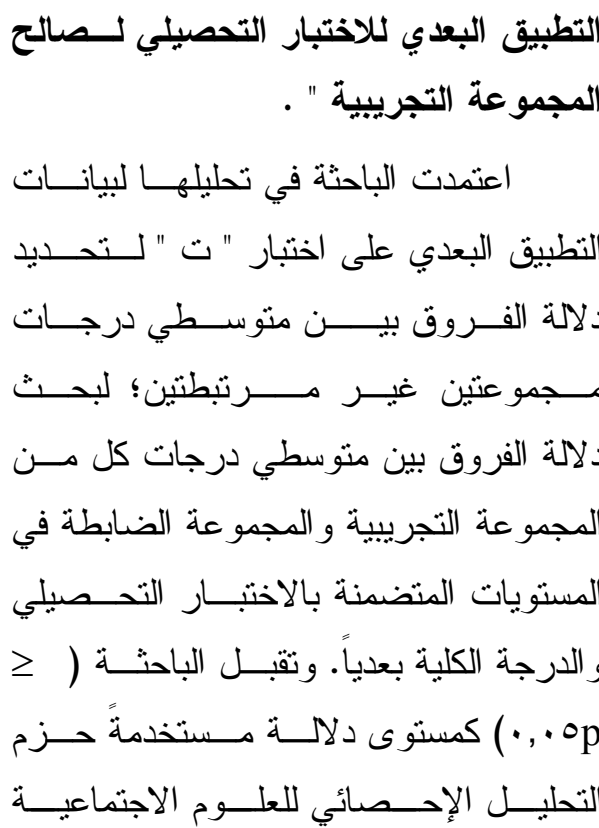

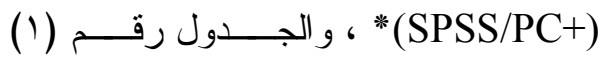
يوضح تلك النتائج :

* SPSS/PC+: Statistical Package for Social Sciences.
ما التصور المقترح لتطوير محتــوى

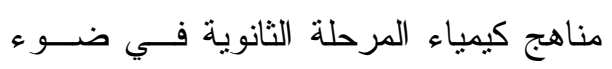
المفاهيم المستعرضة المتضمنة في معسايير الجيل القادم للعلوم (NGSS) ؟ وللإجابة على السؤال الـسـابق تــــ

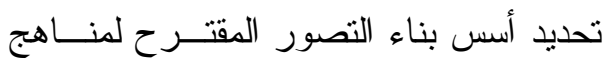

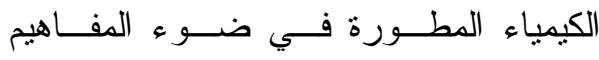
المستعرضة المتضمنة في معسايير الجيــل القادم للعلوم (NGSS) ، وتم وضع التصور

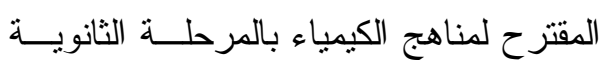
بالثفصيل في الفصل الثالث . • مرابعًا: النتائج المتعلقة بالإجابـة عـن السؤال الرابع ، مناقشتها وتفسيرها : وللإجابة على السؤال الرابــع مـنـ

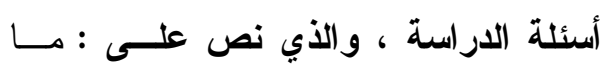

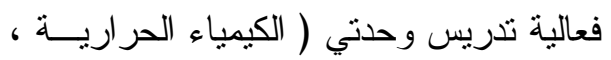

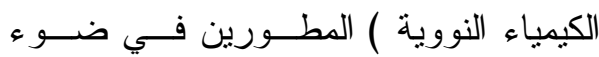
المفاهيم المستعرضة المتضمنة في معسايير الجيل القادم للعـــوم (NGSS) فـــي تتميــة

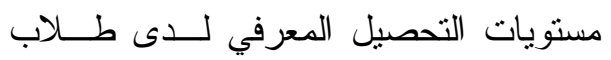
الصف الأول الثانوي ؟ وللتحقق من صحة الفرض الأول الذى ينص على : " يوجد فرق دال إحصائيًا عند مستوى دلالة ه . , · بــين متوســطي درجــات طـــلاب

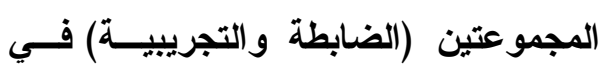


(1) جدول

قيمة "ت" ودلالتها الإحصائية للفروق بين متوسطي درجات كل من المجموعتين (التجريبية

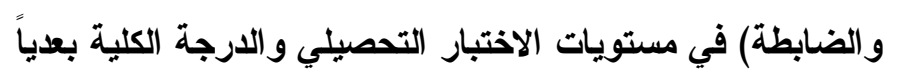

\begin{tabular}{|c|c|c|c|c|c|c|c|}
\hline مستوى الدلاة & الحرية df درجة & قيم (ت) & المعياري & المتوسط & العدد & مجموعتا & التحصتبار \\
\hline$\cdot, \cdot 1$ & A. & $V, \wedge 0$ & $1,0 \leqslant$ & $\varepsilon, r_{4}$ & $\varepsilon r$ & تجرييية & تذكر \\
\hline دالة & & & $1, r$. & $1, \wedge \Lambda$ & $\varepsilon$. & ضابطة & \\
\hline $9, \cdot 1$ & $\lambda$. & $\lambda, r$ & $1, \pi$ & 0,91 & $\varepsilon r$ & تجر بيبة & فهر \\
\hline دالة & & & 1,91 & $r, V r$ & $\varepsilon$. & ضابطة & \\
\hline$\cdot, \cdot 1$ & $\lambda$. & $|\cdot, r|$ & $1, \pi r$ & $7, \Gamma \wedge$ & $\varepsilon r$ & تجريبية & تطبيق \\
\hline دالة & & & $1, \wedge$. & r,or & $\varepsilon$. & ضابطة & \\
\hline$\cdot, \cdot 1$ & A. & $1 ., 90$ & $\varepsilon, r_{O}$ & 11,90 & $\varepsilon r$ & تجرييية & مستويات \\
\hline دالة & & & 1,9 . & $r, q r$ & $\varepsilon$. & ضابطة & عليا \\
\hline.,$\cdot 1$ & $\Lambda$. & 11,09 & $V, q Y$ & $r \wedge, 7 \vee$ & $\leqslant r$ & تجريبية & الاختبار \\
\hline دالة & & & 0,09 & $11, .0$ & $\varepsilon$. & ضابطة & ككل \\
\hline
\end{tabular}

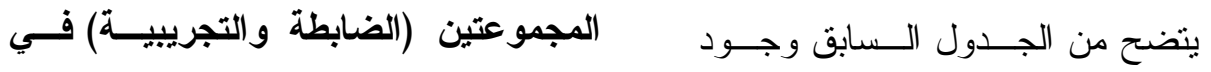

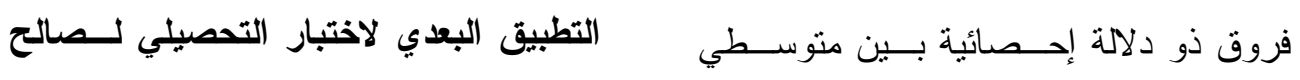

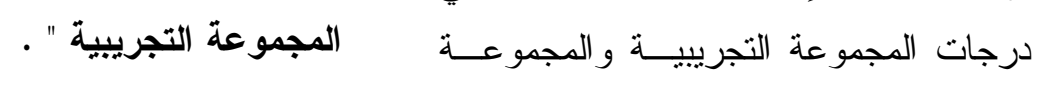

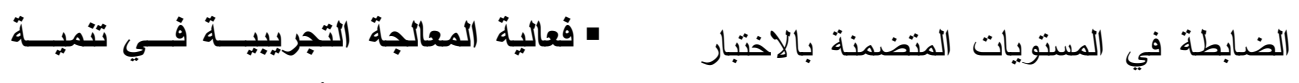

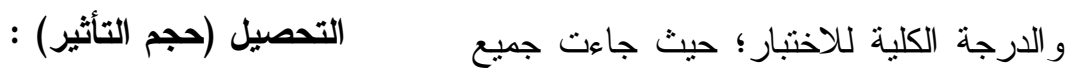

لتحديد فعالية المعالجة التجرييية فـي

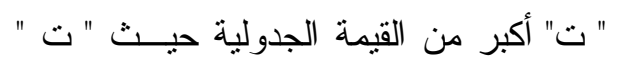

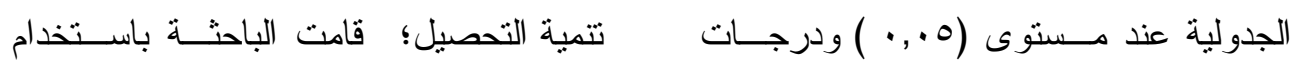

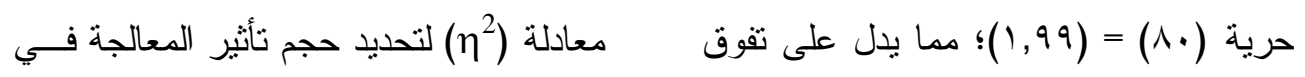

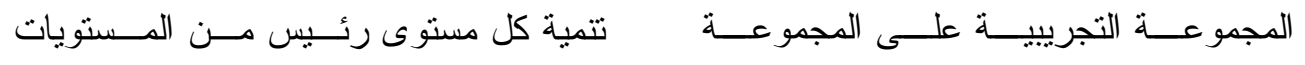

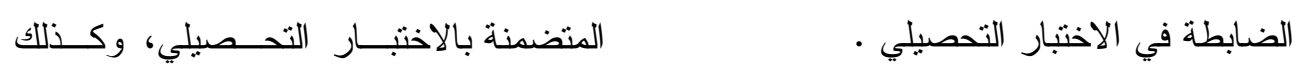

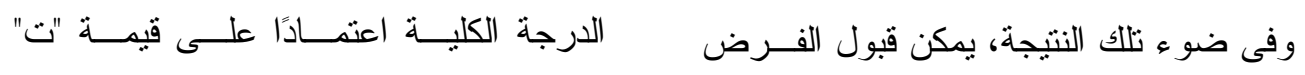

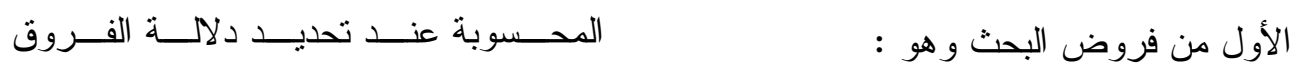

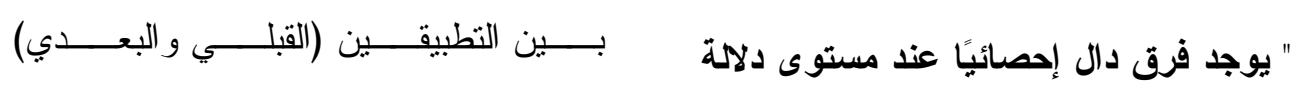

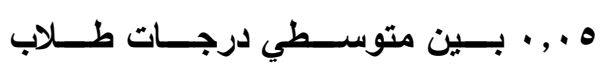


المفاهيم المستعرضة المتضمنة في معسايير

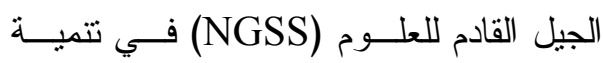

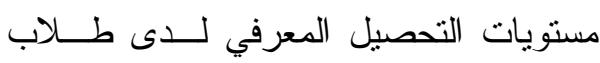

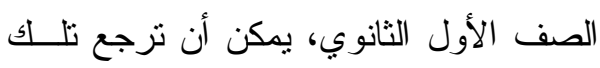

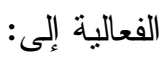

1- أن المنهج المطور بما يحتويسه مــن

أنشطة استقصائية وممارسات علميــة

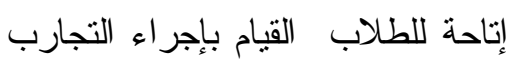

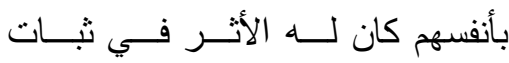

المعلومات في أذهانهم و الذي بـــدوره

يرفع مستوى التحصيل لديهم .

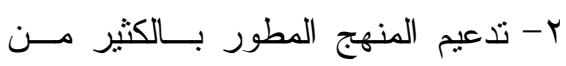

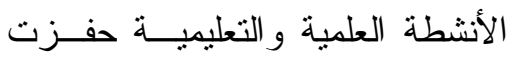

الطلاب على التعلم بـشكل إيجـابي ولئه

ونشط أثناء النطبيق

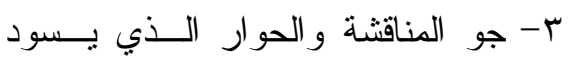

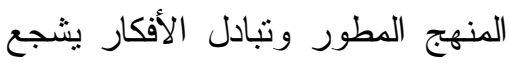

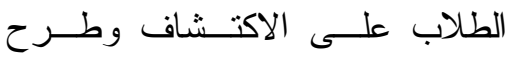

تساؤلات تثير الدافعية لديهم للوصول

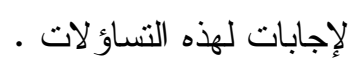

ع- إن المنهج المطور مكن الطلاب مسن

أداء مهام مختلفة تجعهم أكثر نـشـاطًا

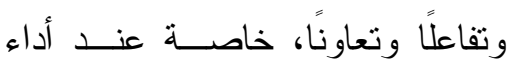

المهام في مجمو عات العمل ممـــا أدى ونى

$$
\text { لارتفاع مستوى التحصيل. }
$$

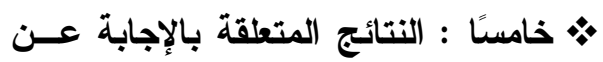

السؤال الخامس ، تفسيرها ومناقشتها:
للمجموعة التجريبية، و الجــدول رقـم (2) يوضح ذلك:

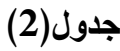

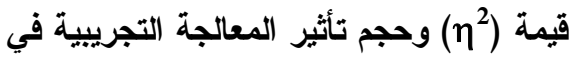
تنمية المستويات الرئيسة للاختبار التحصيلي ولجي لجريل

\begin{tabular}{|c|c|c|c|}
\hline التأثير & $\eta^{2}$ & 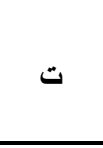 & بالاختبار التحصيلي \\
\hline كبير & $\cdot, \uparrow \Lambda$ & $9, \Sigma \varepsilon$ & تذكر \\
\hline كبير & דו, & $\Lambda, 97$ & فهر \\
\hline كبير & $\cdot, \wedge$. & $1 Y, 9 \leq$ & تطبيق \\
\hline كبير & $\cdot, \mathrm{VV}$ & $11, \wedge \Lambda$ & مستويات عليا \\
\hline كبير & . & $1 T, . r$ & الاختبار ككل \\
\hline
\end{tabular}

والارجة الكلية

يتضح من الجدول السابق أن قيم

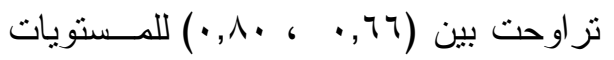

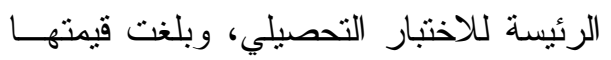

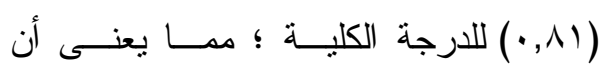

المعالجة التجريبية تسهم في التباين الحــادث

في المستويات الرئيسة للاختبار التحــصيلي

بنسبة ايN\%، مدا بدل على فعالية المعالجة

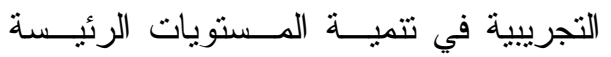

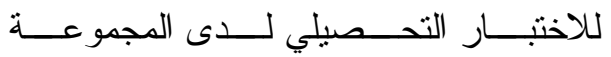

التجريبية.

تفسير النتائج المتعلقة بالإجابة عن السؤال

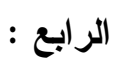

من خلال ما أظهرته النتائج من فعاليـــة

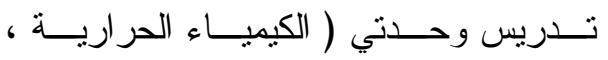

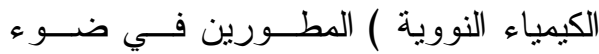


المجموعتين (الضابطة والتجريبيـة) فــي

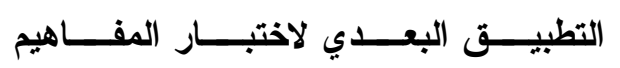
المستعرضة لصالح المجموعة التجريبية " .

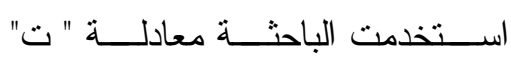

لمجموعتين غبر مرتبطنين؛ لبحــث دلالـــة

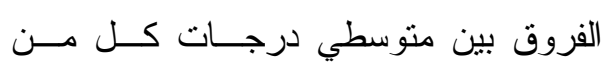
المجموعة التجريبية و المجموعة الضابطة في دئ دربئ

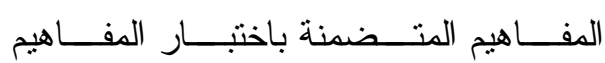

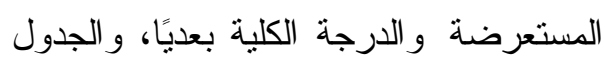
رقم (3) يوضح تلك النتائج :
للإجابة على السؤال الخــامس مـن

أسئلة الدراسة والذي نص على : ما فعالية

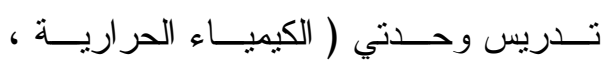

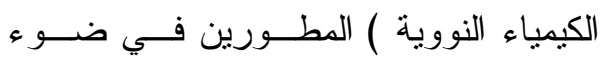
المفاهيم المستعرضة المتضمنة في معسايير

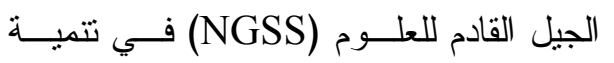

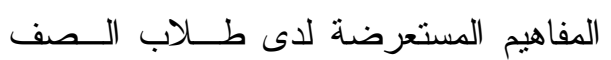

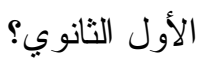
وللتحقق من صحة الفرض الثالــث الــــى ينص على : n :

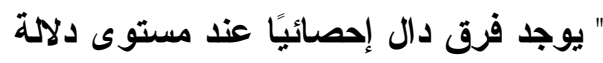

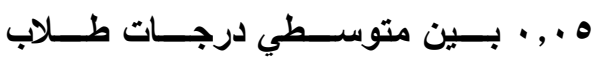

جدول (3) (3ن)

قيمة "ت" ودلالتها الإحصائية للفروق بين متوسطي درجات كل من المجموعتين (التجريبية

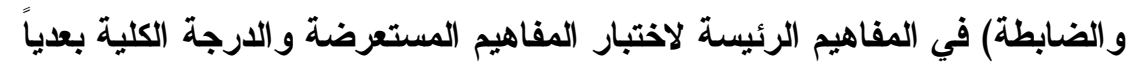

\begin{tabular}{|c|c|c|c|c|c|c|c|}
\hline مستوى الالاية & الحرية دf & قيم (ت) & الآحر اف & المتوسط & العدد العد & مجموعتا & المفاهيم الرئيسة باختبار \\
\hline$\cdot, \cdot 1$ & $\Lambda$. & $\Lambda, r q$ & $r, 7 r$ & $\Lambda, r \wedge$ & $\leqslant r$ & تجريبية & الأنماط \\
\hline دالة & & & $1, \sum r$ & $\xi, \xi \Lambda$ & $\varepsilon$. & ضابطة & \\
\hline$\cdot, \cdot 1$ & $\wedge$. & $9, Y T$ & $1, \wedge \wedge$ & V,rT & $\varepsilon r$ & تجريبية & السبب \\
\hline دالة & & & 1,19 & $\varepsilon, 1$. & $\varepsilon$ & ضابطة & والنتيجة \\
\hline$\cdot, \cdot 1$ & $\Lambda$. & $\Lambda, 11$ & $r, 77$ & $\mathrm{~V}, \wedge 1$ & $\varepsilon r$ & تجرييية & المقياس \\
\hline دالة & & & $1, .0$ & $\varepsilon, 10$ & $\varepsilon$. & ضابطة & و التناسب والكمية \\
\hline$\cdot, \cdot 1$ & $\Lambda$. & $9, Y_{0}$ & $r, \Sigma 1$ & $\Lambda, Y T$ & $\sum r$ & تجريبية & الأظمة \\
\hline دالة & & & 1,1 . & $\varepsilon, \varepsilon$. & $\varepsilon$ & ضابطة & ونماذجها \\
\hline.,+1 & $\Lambda$. & $1 \cdot, 71$ & $r, \cdot \varepsilon$ & $\Lambda, \cdot r$ & $\sum r$ & تجريبية & الطاقة \\
\hline دالة & & & $1, r V$ & $r, 9$. & $\varepsilon$ & ضابطة & و المـادة \\
\hline$\cdot, \cdot 1$ & $\Lambda$. & $9,0 \mathrm{~V}$ & $r, Y Y$ & 1,19 & $\varepsilon r$ & تجريبية & التركيب \\
\hline دالة & & & $1, r q$ & $\varepsilon, \pi T$ & $\varepsilon$ & ضابطة & و الوظيفة \\
\hline$\cdot, \cdot 1$ & $\Lambda$. & 9,0 . & $r, \cdot r$ & $\Lambda, Y_{1}$ & $\sum r$ & تجريبية & الثبات \\
\hline دالة & & & $1, \leqslant 1$ & $\varepsilon, 0 T$ & $\varepsilon$. & ضابطة & و التغير \\
\hline$\cdot, \cdot 1$ & $\Lambda$. & 11,01 & $\Lambda, r \leq$ & $07, Y 1$ & $\leq r$ & تجريبية & الاختبار \\
\hline دالة & & & $r, r \wedge$ & $r q, \wedge \wedge$ & $\varepsilon$ & ضابطة & ككل \\
\hline
\end{tabular}


التطبيــــق البعـــــي لاختبــــــار المفــــاهيم

المستعرضة لصالح المجموعة التجريبية " .

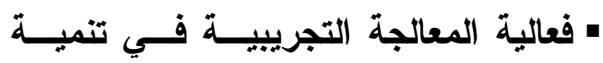
المفاهيم المستعرضة (حجم التأثير) :

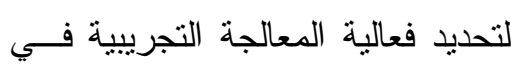

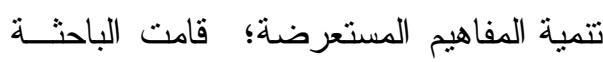

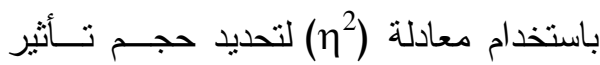

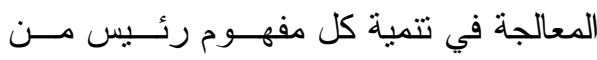

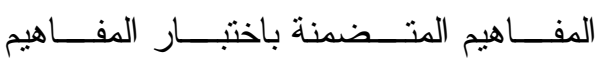
المستعرضة، وكذلك الدرجة الكلية اعتمـاداً

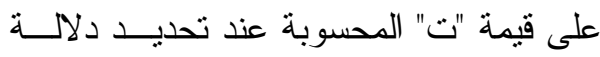
الفروق بين التطبيةـين (القبلــي و البعــدي)

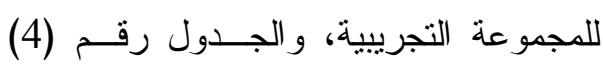
يوضح ذلك :

$$
\begin{aligned}
& \text { يتضح من الجــدول الــــابق وجـود }
\end{aligned}
$$

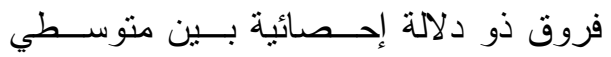

$$
\begin{aligned}
& \text { درجات المجموعة التجريييــة و المجموعــة } \\
& \text { الضابطة في المفاهيم المتـضـنة بالاختبــار } \\
& \text { و الدرجة الكلية للاختبار؛ حيث جاءت جميع }
\end{aligned}
$$

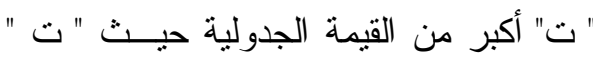

$$
\begin{aligned}
& \text { الجدولية عند مسستوى (0., • ) ودرجـات } \\
& \text { حرية (·^) = (1,99)؛ مما يدل على تفوق }
\end{aligned}
$$

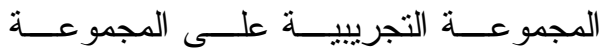

$$
\begin{aligned}
& \text { الضابطة في اختبار المفاهيم المستعرضة . }
\end{aligned}
$$

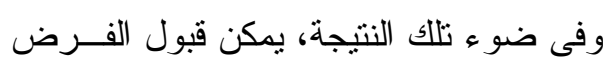

$$
\begin{aligned}
& \text { الثالث من فروض البحث وهو : }
\end{aligned}
$$

\begin{tabular}{|c|c|c|c|}
\hline حجم التأثير & $\eta^{2}$ & $ت$ & المفاهيم الرئيسة باختبار المفاهيم المستعرضة \\
\hline كبير & 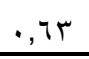 & $\Lambda, r \varepsilon$ & الأنماط \\
\hline كبير & $\cdot, \mathrm{v}_{0}$ & $1 ., 97$ & السبب و النتيجة \\
\hline كبير &.,$\pi$ & $\Lambda, 10$ & المقياس و التتاسب و الكمية \\
\hline كبير & $\cdot, \mathrm{v} \cdot$ & $9, \wedge \vee$ & الأنظمة ونماذجها \\
\hline كبير & $\cdot, \vee \vee 9$ & Ir,rq & الطاقة و المادة \\
\hline كبير &., $7 \leqslant$ & $\wedge, \varepsilon 0$ & التركيب والوظيفة \\
\hline كبير & $\cdot, v_{1}$ & $1 \cdot, \cdot r$ & الثبات و التفير \\
\hline كبيز & $\cdot, \wedge 9$ & 18,97 & الاختبار ككل \\
\hline
\end{tabular}

جدول(4)

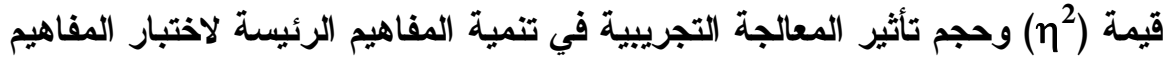
المستعرضة والارجة الكلية 
ك إن المــنهج المطـــور يتــيح للطــلاب

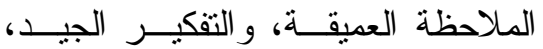

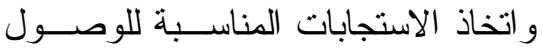
لاستتتاجات سليمة، و هو ما أدى لنتميــة لتونة

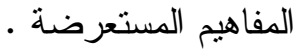
هـ المنهج المطور ساعد الطلاب علي فهــ أعمق للأفكار الجوهرية سواء في العلوم او الهندسة وهذا ما تتادي به المفــاهيم

$$
\text { المستعرضة . }
$$

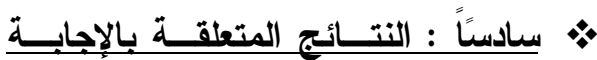
على الـسؤوال الــسادس ، مناقـشتهيا وتفسيرها:

وللإجابة على السؤال السادس مـن

أسئلة الاراسة والذي نص على : ما فعالية

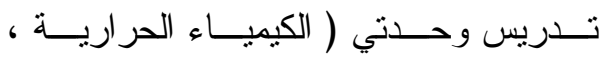

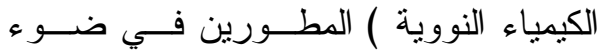
المفاهيم المستعرضة المتضمنة في معسايير الجيل القادم للعلــوم (NGSS) فــي تتميـــة

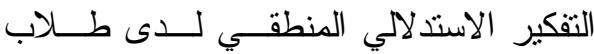
الصف الأول الثانوي ؟ الأبي وللتحقق من صحة الفرض الخــامس الــذـى

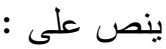

" يوجد فرق دال إحصائيًا عند مستوى دلالة

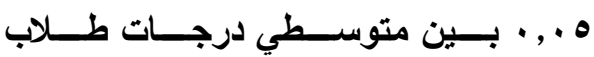

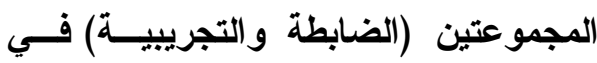
التطبيق البعدي لاختبار التفكير الاســتـلالي وليدي المنطقي لصالح المجموعة التجريبية " .
يتضح من الجدول السابق أن قيم

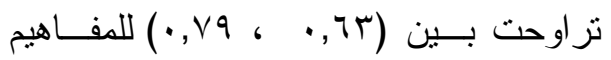

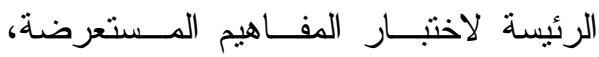

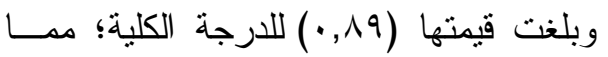
يعنى أن المعالجة التجريبية نسهم في التباين الحادث في المفاهيم الرئيسة لاختبار المفاهيم

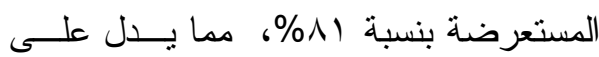
فعالية المعالجة التجريبية في نتمية المفــاهيم

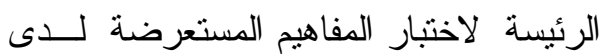
المجموعة التجريبية . تفسير النتائج المتعلقة بالإجابة عن السؤال

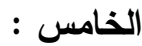
من خلال ما أظهرته النتائج من فعالية تــدريس وحــني ( الكيميــاء الحر اريــة ،

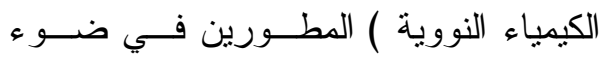
المفاهيم المستعرضة المنضمنة في معسايير

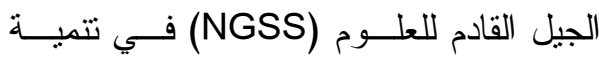

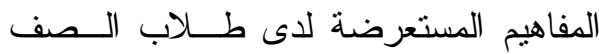
الأول الثانوي، يمكن أن نزجع تلكـ الفعاليـــة إلى : \& أن المنهج المطور يتيح الفرصة للطلاب لملاحظة الأنماط، وطرح التـساؤلات،

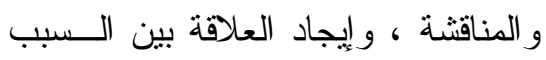
و النتيجة؛ مما أدى إلى تتمية المفــــاهيم المستعرضة لديهم • 
المهــــار ات المتــــمنة باختبــــار التفكيـــر

الاستدلالي المنطقي و الدرجة الكلية بعــدياً،

و الجدول رفم (5) يوضح تللك النتائج:

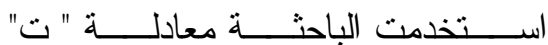

لمجمو عتين غير مرتبطتين؛ لبحـــث دلالـــة الفروق بين متوسطي درجـات كـلـ مــن المجموعة التجريبية و المجمو عة الضـابطة في

جدول (5)

قيمة "ت" ودلالتها الإحصائية للفروق بين متوسطي درجات كل من المجموعتين (التجريبية والضابطة) في المهار ات الرئيسة لاختبار التفكير الاستدلالي المنطقي والارجة الكلية بعدياً

\begin{tabular}{|c|c|c|c|c|c|c|c|}
\hline مستوى & 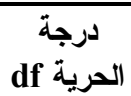 & قيم (ت) & الاتحر افياري & المتوسط & العدد & مجموعتا & الاستدلاري المنطقي \\
\hline$\cdot, \cdot 1$ & $\Lambda$. & $11, .9$ & 1,94 & 0,19 & $\varepsilon r$ & تجريبية & ضبط \\
\hline دالة & & & $1, Y_{1}$ & $1, Y r$ & $\varepsilon$. & ضابطة & المتغير ات \\
\hline$\cdot, \cdot 1$ & $\Lambda$. & $\lambda, r \varepsilon$ & 1,99 & $0,1 \mathrm{~V}$ & $\varepsilon r$ & تجريبية & الاستدلال \\
\hline دالة & & & 1,94 & 1,7 & $\varepsilon$. & ضابطة & الاحتفاظي \\
\hline$\cdot, \cdot 1$ & $\Lambda$. & $9, \Gamma 0$ & $1, \mathrm{r \Lambda}$ & $r, v \varepsilon$ & $\varepsilon r$ & تجريبية & الاستتلال \\
\hline دالة & & & 1,19 & $\cdot, 91$ & $\varepsilon$ & ضابطة & التناسبي \\
\hline.,$\cdot 1$ & $\Lambda$. & $q, \Gamma \varepsilon$ & $1,7 \pi$ & 0,19 & $\varepsilon r$ & تجرييية & الاستدلال \\
\hline دالة & & & 1,10 & 1,7 . & $\varepsilon$. & ضابطة & الاحتمالى \\
\hline$\cdot, \cdot 1$ & $\Lambda$. & $1 r, v$. & $r, 1$. & $7, \wedge 1$ & $\varepsilon r$ & تجرييية & الاستدلال \\
\hline دالة & & & $1, \leqslant 1$ & $1, \mathrm{rA}$ & $\varepsilon$. & ضابطة & الارتباطي \\
\hline$\cdot, \cdot 1$ & $\wedge$. & 9,74 & $1, r$. & $r, r_{1}$ & $\sum r$ & تجريبية & الاستـلال \\
\hline دالة & & & $\cdot, 97$ & $\cdot, 9$. & $\varepsilon$. & ضابطة & التو اقفي \\
\hline., .1 & $\Lambda$. & YY,rI & \&, & rq,r। & $\varepsilon r$ & تجرييية & الاختبار \\
\hline دالة & & & $\varepsilon, \varepsilon V$ & $\vee, 7 \wedge$ & $\varepsilon$. & ضابطة & ككل \\
\hline
\end{tabular}

يتضح من الجــدول الــسابق وجــود الضـابطة في اختبــار التفكيـر الاســــلالي فروق ذو دلالة إحــصائية بــين منوســـي المنطقي.

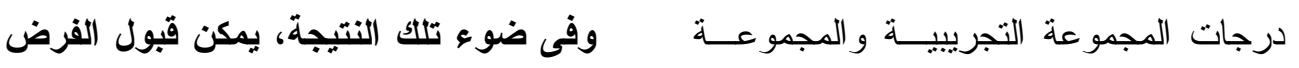
الضابطة في المهار ات المتضمنة بالاختبـار الخامس من فروض البحث وهو : و الدرجة الكلية للاختبار؛ حيث جاءت جميع يوجد فرق دال إحصائيًا عند مستوى دلالة

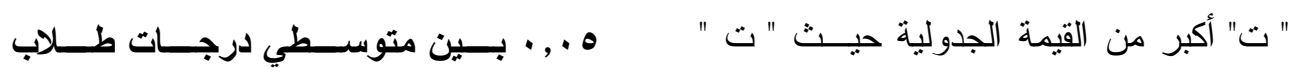

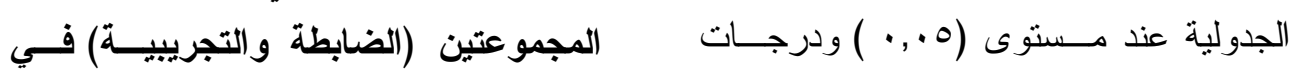

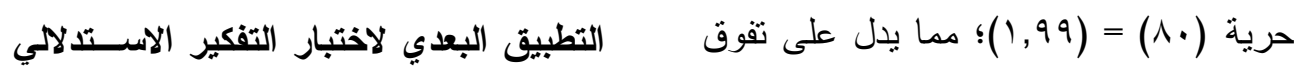

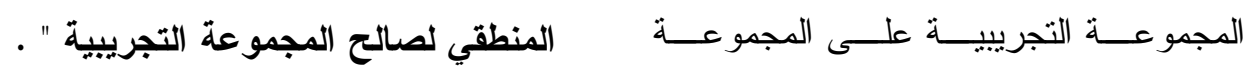


يتضح من الجدول السابق أن قيم

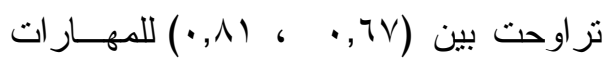
الرئيسة لاختبار التفكير الاستدلالي المنطقي، لئن

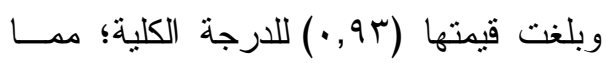
يعنى أن المعالجة التجريبية تسهم في التباين الحادث في المهارات الرئيسة لاختبار التفكير الاستدلالي المنطقي بنسبة ب9\%، مها بــدل

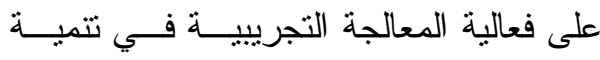
المهار ات الرئيسة لاختبار التفكير الاستدلالي لئي لئهي المنطقي لدى المجمو عة التجريبية . تفسير النتائج المتعلقة بالإجابة عن السؤال السادس :

من خلال ما أظهرته النتائج من فعالية

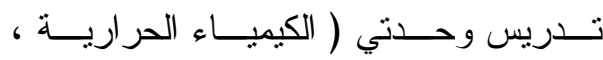

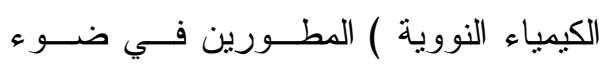
المفاهيم المستعرضة المتضمنة في معسايير

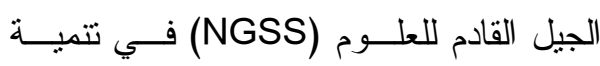

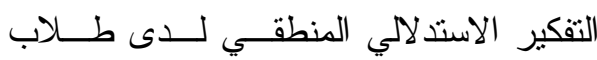

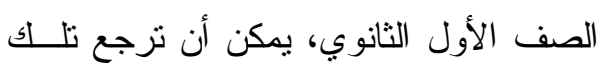

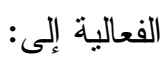
ه يسمح المنهج المطور للطالب أن يتوقع

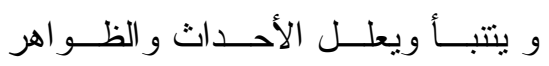
المختلفة التي تو اجهه أثناء تتفيذه لار اسة ولنة مهارة عملية مما أدى إلى تتمية التفكير الاستدلالي المنطقي.

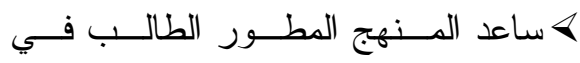
التوصــلـل إلــى معلومــــات جديـــــة
ـ فعالية المعالجة التجريبيــة فــي تنميــة

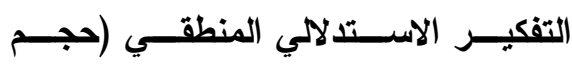
(التأثير):

لتحديد فعالية المعالجة التجريبية فـي

تتمية التفكير الاستدلالي المنطقي ؛ قامــــ

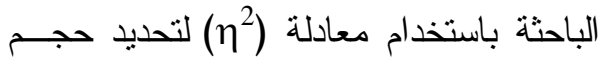

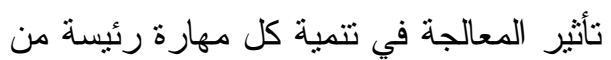

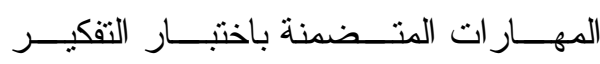
الاستخلالي المنطقي، وكذلك الدرجة الكليــة

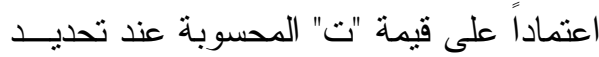
دلالة الفروق بين النطبيقين (القبلي و البعدي)

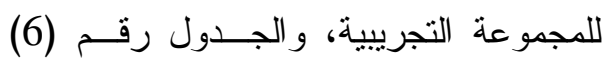
يوضح ذللك : جدول(6) قيمة ( في تنمية المهار ات الرئيسة لاختبار التفكير الاستدلالي المنطقي والدرجة الكلية

\begin{tabular}{|c|c|c|c|}
\hline التأثير & $\eta^{2}$ & 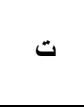 & مهارات اختبار التفكير \\
\hline كبير & $\cdot, \vee \vee q$ & 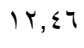 & ضبط المتغيرات \\
\hline كبير & $\cdot, \mathrm{\vee} \wedge$ & $\mathbb{k}, \cdot \varepsilon$ & الاستدلال الاحتفاظي \\
\hline كبير & $\cdot, \mathrm{VV}$ & $11, \wedge \varepsilon$ & الاستدلال التناسبي \\
\hline كبير & $\cdot, \wedge)$ & $1 r, \cdot \varepsilon$ & الاستدلال الاحتمالي \\
\hline كبير & $\cdot, \wedge$. & Ir,NT & الاستدلال الارتباطي \\
\hline كبير & $\cdot, T V$ & $9, \cdot r$ & الاستدلال التو افقي \\
\hline كبير & $\cdot, 94$ & $r \Lambda, \Lambda$. & الاختبار ككل \\
\hline
\end{tabular}




$$
\begin{aligned}
& \text { و استخلاص دلالات من المعرفة العلمية المفاهيم المستعرضة المتضمنة في معسايير }
\end{aligned}
$$

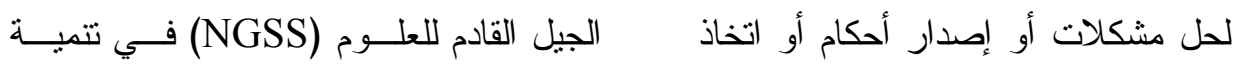

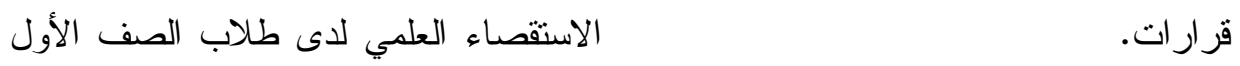

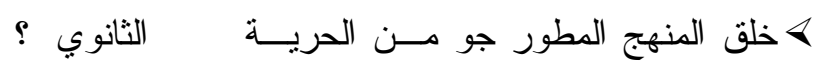

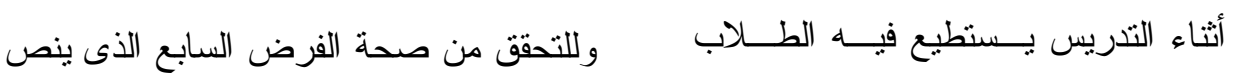

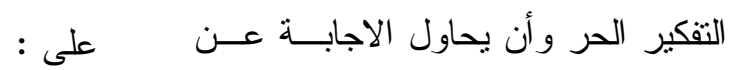

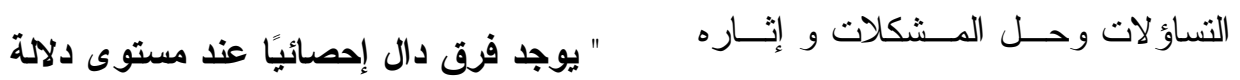

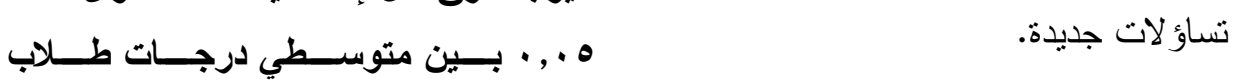

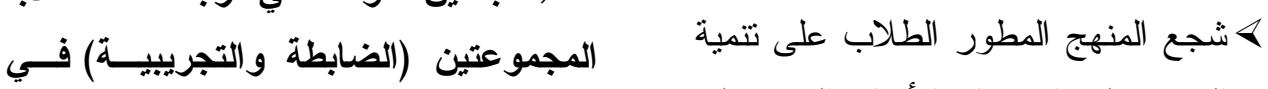

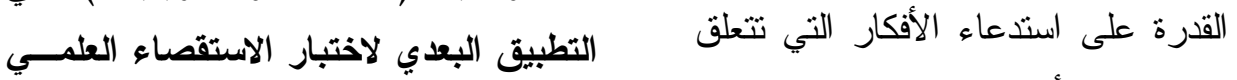

$$
\begin{aligned}
& \text { بحل مشكلة أو فرض الفـروض التـي لصنالح المجموعة التجريبية " . ل }
\end{aligned}
$$

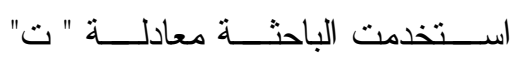

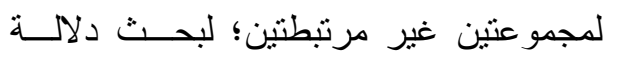

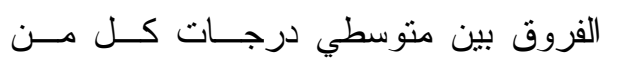

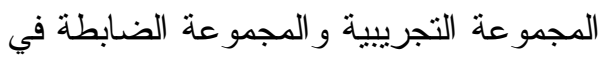

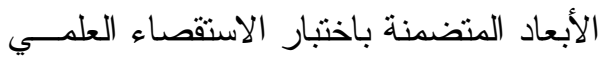

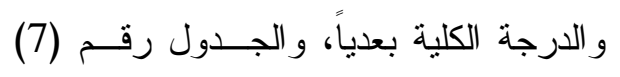

$$
\begin{aligned}
& \text { يوضح تلك النتائج : }
\end{aligned}
$$

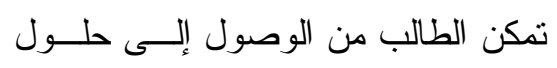

$$
\begin{aligned}
& \text { المشكلة. }
\end{aligned}
$$




\section{جدول (7)}

قيمة "ت" ودلالتها الإحصائية للفروق بين متوسطي درجات كل من المجموعتين (التجريبية

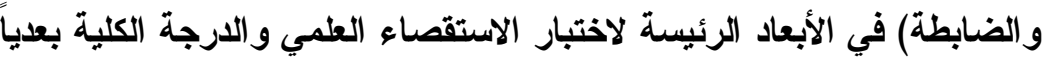

\begin{tabular}{|c|c|c|c|c|c|c|c|}
\hline مستوى & الحرية دf درة & قيم (ت) & الاحعراف & المتوسط & العدد & مجموعتا & الاستقصاء ألتبار \\
\hline$\cdot, \cdot 1$ & ᄉ. & $9, \wedge q$ & $1, \lambda r$ & $\varepsilon, \wedge \uparrow$ & $\varepsilon r$ & تجرييية & طرح \\
\hline دالة & & & $1, \varepsilon 1$ & $1, r \wedge$ & $\varepsilon$ & ضابطة & الأسئلة \\
\hline$\cdot, \cdot 1$ & $\wedge$. & 9,01 & 1,07 & $r, 90$ & $\varepsilon r$ & تجرييية & تصميم الأنثطة \\
\hline دالة & & & $1,1$. & $1,1$. & $\varepsilon$ & ضابطة & و التجارب \\
\hline$\cdot, \cdot 1$ & $\wedge$. & 9,11 & $1,7 \mathrm{~V}$ & $\varepsilon, 0$. & $\varepsilon r$ & تجرييية & جمع البيانات \\
\hline دالة & & & $1, \varepsilon V$ & $1, r r$ & $\varepsilon$ & ضابطة & وتحليلها \\
\hline$\cdot, \cdot 1$ & ᄉ. & $1, ., 0$ & $1, \pi$ & $\varepsilon, 91$ & $\varepsilon r$ & تجرييية & التفسير \\
\hline دالة & & & 1,71 & $1, r \wedge$ & $\varepsilon$ & ضابطة & \\
\hline$\cdot, \cdot 1$ & $\wedge$. & $1 \cdot, 7$ & 1,17 & $\varepsilon, \leqslant 0$ & $\varepsilon r$ & تجرييية & صياغة \\
\hline دالة & & & $1, \cdot r$ &., 9. & $\varepsilon$ & ضابطة & النماذج \\
\hline., .1 & $\Lambda$. & $r \cdot, \wedge 0$ & $\varepsilon, Y$ & rr,V & $\varepsilon r$ & تجريبية & الاختبار \\
\hline دالة & & & r,q) & 0,91 & $\varepsilon$ & ضابطة & ككل \\
\hline
\end{tabular}

يتضح من الجـدول الـسابق وجــود " يوجد فرق دال إحصائيًا عند مستوى دلالة

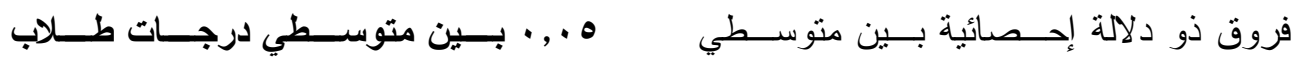

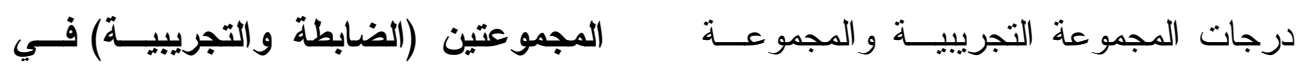

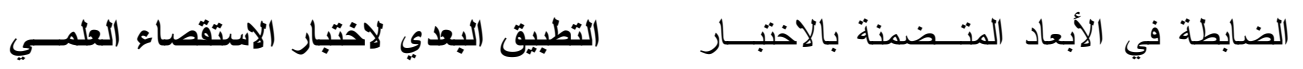

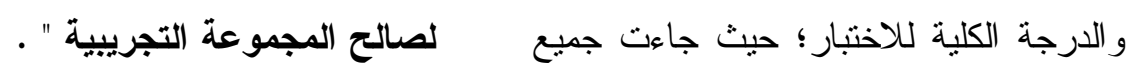

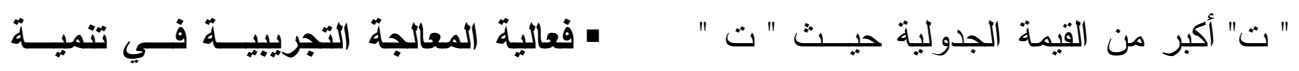
الجدولية عند مسستوى (0., ) ) ودرجـات الاستقصاء العلمي (حجم التأثير) :

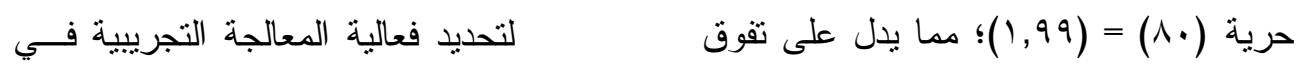

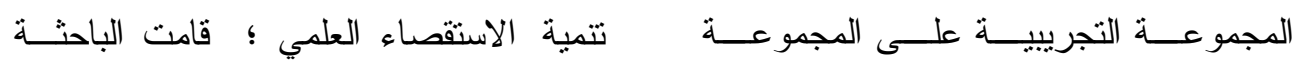

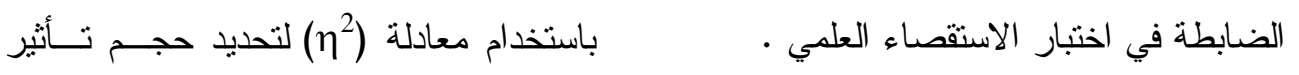
وفى ضوء تلك النتيجة، يمكن قبول الفرض المعالجة في تتمية كل بعد رئيس من الأبعاد

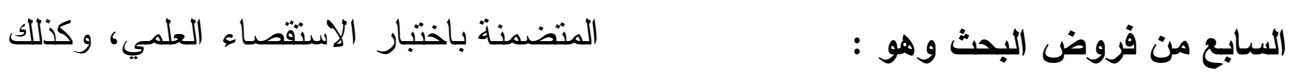


تفسير النتائج المتعلقة بالإجابة عن السؤال السابع : - (الس

من خلال ما أظهرته النتائج من

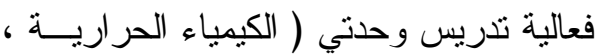

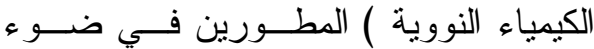

المفاهيم المستعرضة المتضمنة في معسايير

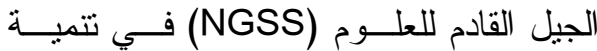

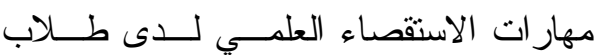

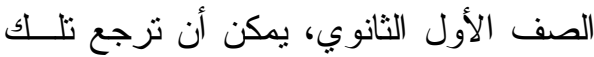

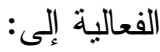

> عزز المنهج المطور الفـضولية وحـب

الاستطلاع لدى الطالب لاكتشاف البيئـــة

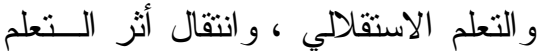

حيث يكنسب المتعلم الأنماط و الأساليب الي تمكنه من التوصل إلى القرار وحل

المشكلات ووضع إجابات للأسئلة الــي لـي لـي

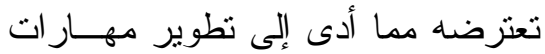

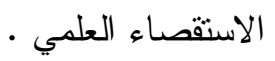

هاعد المنهج المطور الطالب على تمثيل

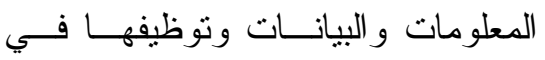
مو اقف حل المشكلات > نمى المنهج المطور قدرة الطالب علــى التفكير الابتكاري ومعالجة المعلومــات حيث يجد المتعلم نفسه وبصورة مستمرة

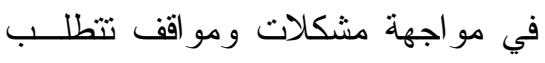

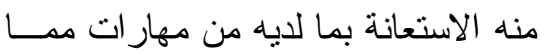

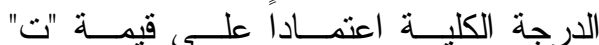
المحسوبة عند تحديد دلالـــة الفـروق بــين التطبيقــين (القبالــي و البعـــي) للمجمو عـــة التجريبية، و الجدول (8) يوضح ذلك : جدول(8)

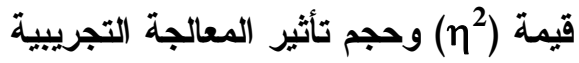
في تنمية الأبعاد الرئيسة

للاختبار الاستقصاء العلمي والارجة الكلية

\begin{tabular}{|c|c|c|c|}
\hline التأثير & $\eta^{2}$ & 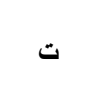 & الاستقصاء الغتبلر \\
\hline كبير & $\cdot, \mathrm{VT}$ & Tr, & طرح الأسئلة \\
\hline كبير & $\cdot, \mathrm{VV}$ & $11, v$. & تصميم الأنشطة \\
\hline كبير & $\cdot, \mathrm{V} \leqslant$ & $1 \cdot, v \cdot$ & جمع البياتات وتحليلها \\
\hline كبير & 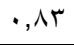 & $1 \varepsilon, 0$ & التفسير \\
\hline كبير & $\cdot, \wedge$ & IT,VY & صياغة النماذج \\
\hline كبير & •, QY & $r_{0, .1}$ & الاختبار ككل \\
\hline
\end{tabular}

يتضح من الجدول السابق أن قيم

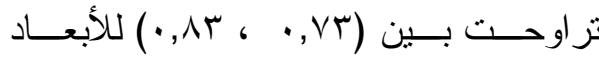
الرئيسة للاختبار الاستقصاء العلمي، وبلغت

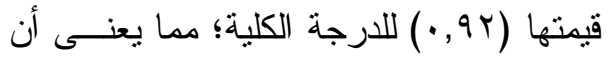
المعالجة التجريبية تسهم في التباين الحــادث

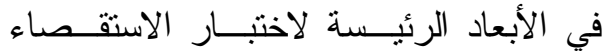

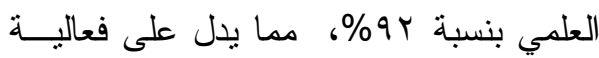
المعالجة التجرييية في تتمية الأبعاد الرئيسـسة لاختبار الاستقصاء العلمي لدى المجموعــة التجريبية . 


$$
\begin{aligned}
& \text { ب- تدل نتائج البحث الحالي علــى تفــوق } \\
& \text { المجموعة التجريبيـــة فــي الاختبـــار }
\end{aligned}
$$

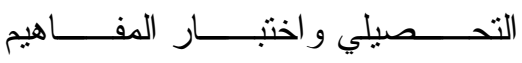

$$
\begin{aligned}
& \text { المستعرضة ، و اختبــار الاســــلالي ولي }
\end{aligned}
$$

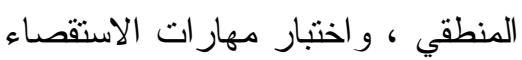

$$
\begin{aligned}
& \text { العلمي، ويرجع ذلك إسـى أن المــنهج }
\end{aligned}
$$

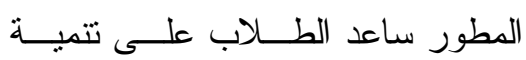

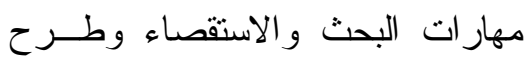

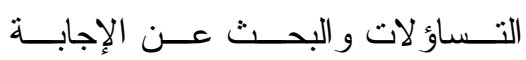

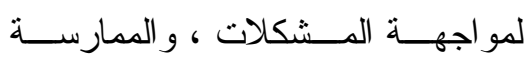

$$
\begin{aligned}
& \text { الفعلية للأنشطة و التجـــارب العمليـــة } \\
& \text { و استخدام شبكة الانتزنت في البحــث }
\end{aligned}
$$

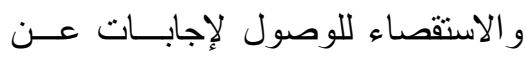

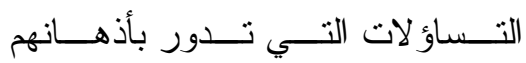

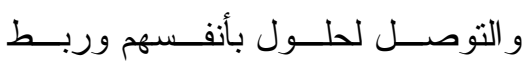

$$
\begin{aligned}
& \text { المعلومات السابقة بالمعلومات الحالية . }
\end{aligned}
$$

المراجع : - الماج

- إسماعيل عيد الهالول، يحي ابو جحجـوح

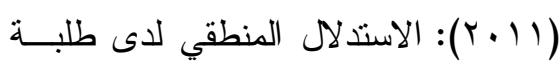

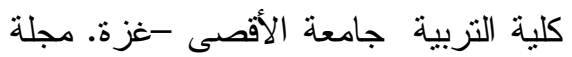
جامعة الأزهر، سلسلة العلوم الإنـسانية،

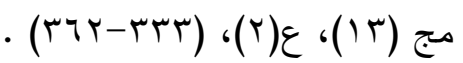

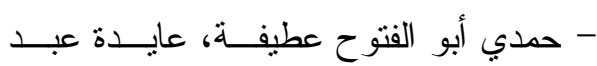

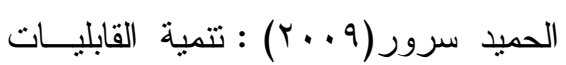

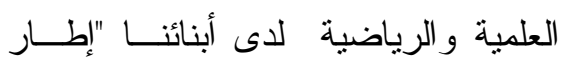

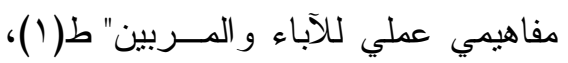
القاهرة، دار النشر للجامعات.
أدى إلى اكتــــاب الطالـــب مهــارات

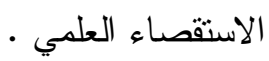

$$
\text { تعليق عام على نتائج البحث }
$$

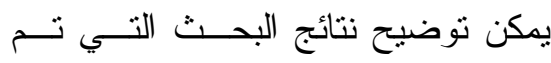

التوصل إليها في ضوء المنهج المطور فــي لني

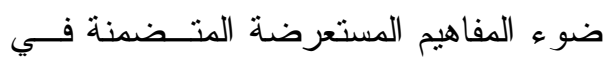

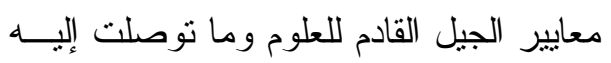
الدر اسات السابقة كما يلي:

1- أوضحت نتائج البحث أن حجم تـأثثر

المنهج المطور على التحــصيل كــان كبيرًا وتتفق هذه النتائج مع نوصل إليه

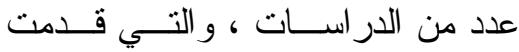
تصور لأهمية وكيفية تطوير منــاهج العلوم في ضوء معايير الجيل القــادم

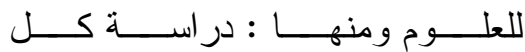

Bسن (Boesdorfer \& Staude ‘,2016

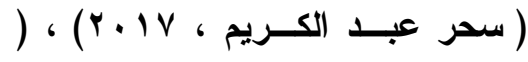

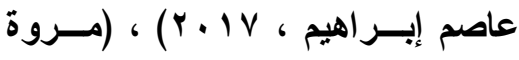

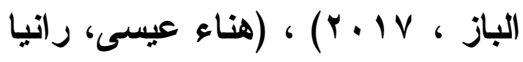
راغب، r- أوضحت نتائج البحث أن حجم تــأثير

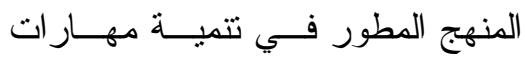

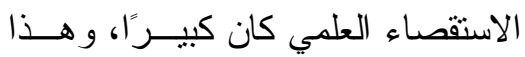
يتفق مع نتائج دراسة (ســـر عبـــ

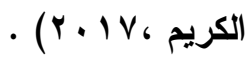




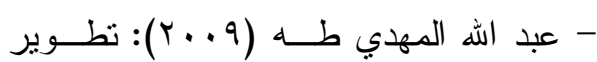
وحدة في العلوم في ضوء المعايير القومية و أثز ها في إكساب المفاهيم العلمية. رسالة فئل ماجيستر ( غير منشورة) ، كلية النربية،

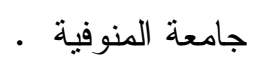

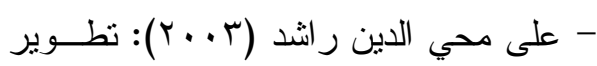

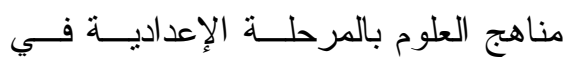
مصر في ضوء المعايير العالمية للتربيــة

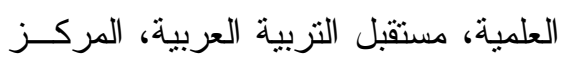

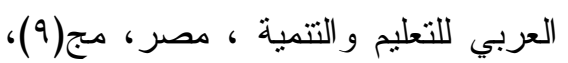

$$
\text { . }
$$

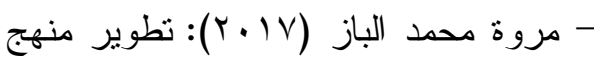

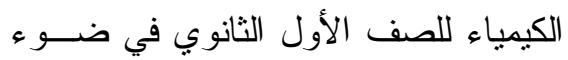
مجال التصميم الهندسي لمعـايير العـــوم للجيل القادم NGSS وأثره فــي تنتميــة

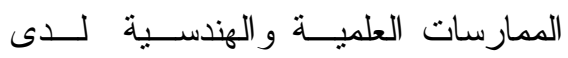
الطلاب، مجلة كلية التربية ، بورسـعيد، ولئه

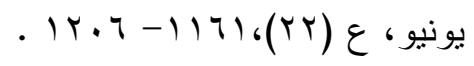

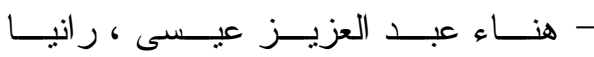

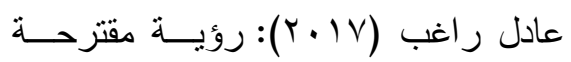

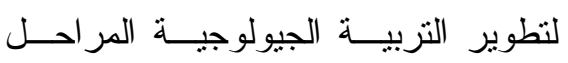

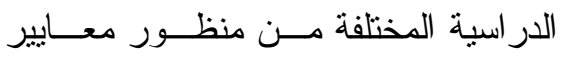
العلوم للجيل القادمNGSS ، مجلة التربية

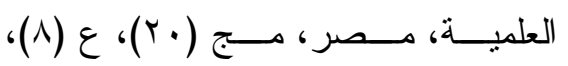
$.197-1 \leqslant r$

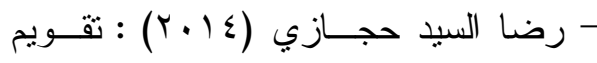
مناهج علوم مرحلــة التعلـيم الأساســي بمصر في ضــوء المعـايير العالميــة للتربية العلمية وتقديرات معلمي العلوم ، فئول دراسات عربية في التزبية وعلم النفس -

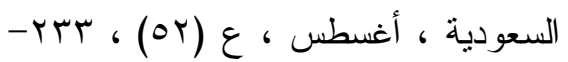

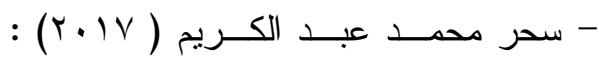
برنامج تدريبي قائم على معسايير العلــوم

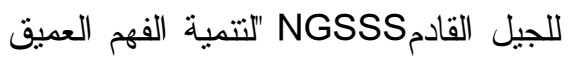
ومهارات الاستقصاء العلمـيـ و الجــل

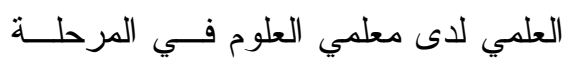

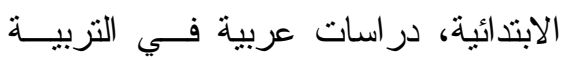

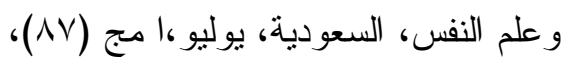
$.111-r \mid$

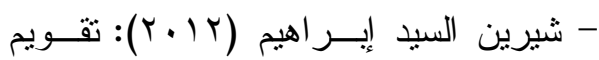
مناهج العلوم بالمرحلة الابتدائية في ضوء الهئ

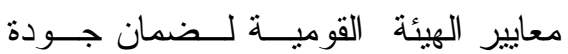
التعليم و الاعتماد، مجلـــة كليــة التربيـــة

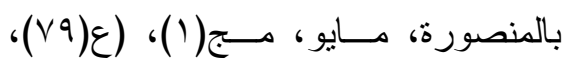
$.09 .-009$ - عاصم محمد إبــر اهيم (Y. V (Y): تقــويم

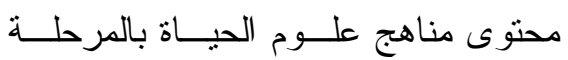

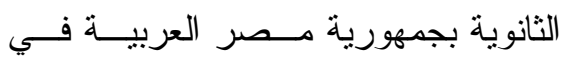
ضوء معايير العلوم للجيل القادم، مجلـــة

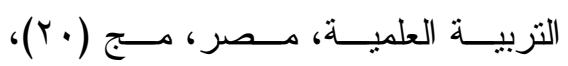
. INt-IrV، (Ir) 
DC: The National Academies Press. California.

- National Research Council. (2015). Guide to Implementing the Next Generation Science Standards. Washington, DC: The National Academies Press.

- National Science Teachers Association. (2013a). About the Next

Generation Science Standards Retrieved November 4, 2017, from

http://ngss.nsta.org/about-thenext-generation-science-

standards.

- NGSS Lead States .(2013). Next Generation Science Standards: For states, by states .Washington DC: The National Academies Press .

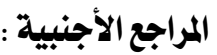

- Boesdorfer, S. B., \& Staude, K. D. (2016). Teachers' practices in high school chemistry just prior to the adoption of the Next Generation Science Standards. School Science and Mathematics, 116(8), 442-458.

- Creswell. J. (2014). Research design: Qualitative, quantitative, and mixed methods approaches. USA: SAGE.

- National Research Council . (1996) . National science education standards. Washington . DC: National Academies Press .

- National Research Council (2012). A Framework for K-12 Science

Education:

Practices,

Crosscutting Concepts, and Core Ideas. Washington, 